\title{
30. LITHOSTRATIGRAPHY, BIOSTRATIGRAPHY, AND STABLE-ISOTOPE STRATIGRAPHY OF CORES FROM ODP LEG 105 SITE SURVEYS, LABRADOR SEA AND BAFFIN BAY ${ }^{1}$
}

\author{
D. B. Scott,${ }^{2}$ P. J. Mudie,${ }^{3}$ A. de Vernal,${ }^{4}$ C. Hillaire-Marcel, V. Baki, ${ }^{4}$ K. D. MacKinnon,${ }^{2}$ F. S. Medioli, ${ }^{2}$ and \\ L. Mayer ${ }^{5}$
}

\begin{abstract}
Trigger weight (TWC) and piston (PC) cores obtained from surveys of the three sites drilled during Ocean Drilling Program (ODP) Leg 105 were studied in detail for benthic foraminiferal assemblages, total carbonate (all sites), planktonic foraminiferal abundances (Sites 645 and 647), and stable isotopes (Sites 646 and 647). These high-resolution data provide the link between modern environmental conditions represented by the sediment in the TWC and the uppermost cores of the ODP holes. This link provides essential control data for interpretating late Pleistocene paleoceanographic records from these core holes. At Site 645 in Baffin Bay, local correlation is difficult because the area is dominated by ice-rafted deposits and by debris flows and/or turbidite sedimentation. At the two Labrador Sea sites (646 and 647), the survey cores and uppermost ODP cores can be correlated. High-resolution data from the site survey cores also provide biostratigraphic data that refine the interpretations compiled from core-catcher samples at each ODP site.
\end{abstract}

\section{INTRODUCTION}

The Labrador Sea is the main corridor linking the subarctic waters of the northwest Atlantic Ocean and the eastern Canadian Arctic seaways (Fig.1). At present, surface currents in the eastern Labrador Sea are the primary source of heat transport to Baffin Bay and West Greenland, while the western Labrador Sea is the main conduit for overflow of cold water from the western Arctic Ocean (Aksu and Mudie, 1985; Andrews et al., 1985). During Pleistocene glacial stages, therefore, surface water conditions in the Labrador Sea and Baffin Bay would have played a major role in the local and meridional transport of moisture to North American and Greenland ice sheets, the distribution and thickness of sea-ice cover, and the formation of bottom water in the western North Atlantic.

Previous studies produced conflicting interpretations of Late Pleistocene paleoenvironmental conditions in the Labrador Sea. Studies of deep-sea cores from the North Atlantic near the southern end of the Labrador Sea (CLIMAP, 1981) and derived global circulation models (Gates, 1976) suggest that the entire Labrador Sea was filled with polar water and sea ice during the late Wisconsinan to early Holocene period. Denton and Hughes (1981) concluded that glacial and thick sea ice filled the region between eastern Canada and Greenland during the Wisconsinan. In contrast, paleoceanographic studies of cores from the continental slope in the northeastern Labrador Sea (Fillon and Duplessy, 1980), from Davis Strait (Mudie and Aksu, 1984; Aksu and Mudie, 1985), and Baffin Bay (Aksu, 1983; Mudie and Short, 1985; Andrews et al., 1985) indicate that subarctic water continued to penetrate into Baffin Bay during most of the Wisconsinan. Fillon et al. (1981) also found an inverse relationship between intervals of ice-transported sand influx to the Labrador Sea and the subpolar central North Atlantic Ocean; this

${ }^{1}$ Srivastava, S. P., Arthur, M., Clement, B., et al., 1989. Proc. ODP, Sci. Results, 105: College Station, TX (Ocean Drilling Program).

2 Centre for Marine Geology, Dalhousie University, Halifax, Nova Scotia B3H 3J5, Canada.

${ }^{3}$ Geological Survey of Canada, Atlantic Geoscience Centre, Box 1006, Dartmouth, Nova Scotia B2Y 4A2, Canada.

${ }^{4}$ GEOTOP, Université de Québec à Montréal, Québec H3C 3P8, Canada.

5 Department of Oceanography, Dalhousie University, Halifax, Nova Scotia B3H 3J5, Canada. relationship implies that histories of ice-sheet expansion and sea-surface temperature are significantly different for the northern and southern regions of the Northwest Atlantic Ocean.

To resolve these apparent contradictions and to establish a detailed paleoceanographic history for the Labrador Sea-Baffin Bay region, Pliocene-Pleistocene sediments at two sites in the Labrador Sea and one site in Baffin Bay were cored continuously during Leg 105 of the Ocean Drilling Program (Srivastava, Arthur, et al., 1987). Two of the sites (Sites 646 and 647) lie on a north-south transect in the Labrador Sea, within the area presently dominated by warm surface currents. Site 647 is at the same latitude as DSDP Leg 94 , Site 611 , drilled on the east flank of the Reykjanes Ridge (Fig. 1). Together these sites provide an east-west profile linking the western and central North Atlantic subarctic regions. Site 646 at $58^{\circ} \mathrm{N}$ occupies a position intermediate between the subarctic North Atlantic and the arctic Baffin Bay Site 645 at about $70^{\circ} \mathrm{N}$.

Here, we describe the results of detailed studies conducted on cores obtained during surveys of the proposed drill sites by Hudson cruises 84-030 and 85-027. During these surveys, piston and gravity cores were obtained in conjunction with high-resolution (Huntec Deep-Tow, $3.5 \mathrm{kHz}$ ) and $12-\mathrm{kHz}$ echosounder profiles of the surficial sediments. These data are used to interpret and correlate regional acoustic and lithostratigraphic units and to establish high-resolution biostratigraphic and stable-isotope profiles for late Quaternary sediments at these ODP drill sites.

\section{METHODS}

Microfossil samples (15 $\mathrm{cm}^{3}$ volume) were taken from 1-2-cm-long intervals spaced approximately every 5 to $10 \mathrm{~cm}$ downcore. The samples were washed through a $63-\mu \mathrm{m}$ sieve mesh; planktonic foraminifers for isotopic studies were selected from the $212-250-\mu \mathrm{m}$ size fraction.

Neogloboquadrina pachyderma (left coiling) was used to obtain ${ }^{18} \mathrm{O} /{ }^{16} \mathrm{O}$ and ${ }^{13} \mathrm{C} /{ }^{12} \mathrm{C}$ isotopic ratios for Cores 84-030-01 and -04 TWC and PC. Measurements were performed using a Micromass 602D system at Dalhousie University (DAL). All samples contained more than 150 specimens. Details of the methods used are given by Scott et al. (1986). Duplicate analyses of the laboratory standards (Carrera marble at DAL; UQ2 at UQAM ) and selected samples show that reproducibility lies in the range of \pm 0.05 to $\pm 0.06 \%$. The isotopic ratios are expressed as per mil $(\%)$ difference from the Chicago PDB standard.

Carbonate analysis was perfomed with the "Karbonat-Bombe" method of Müller and Gastner (1971). The bombe was calibrated with mix- 


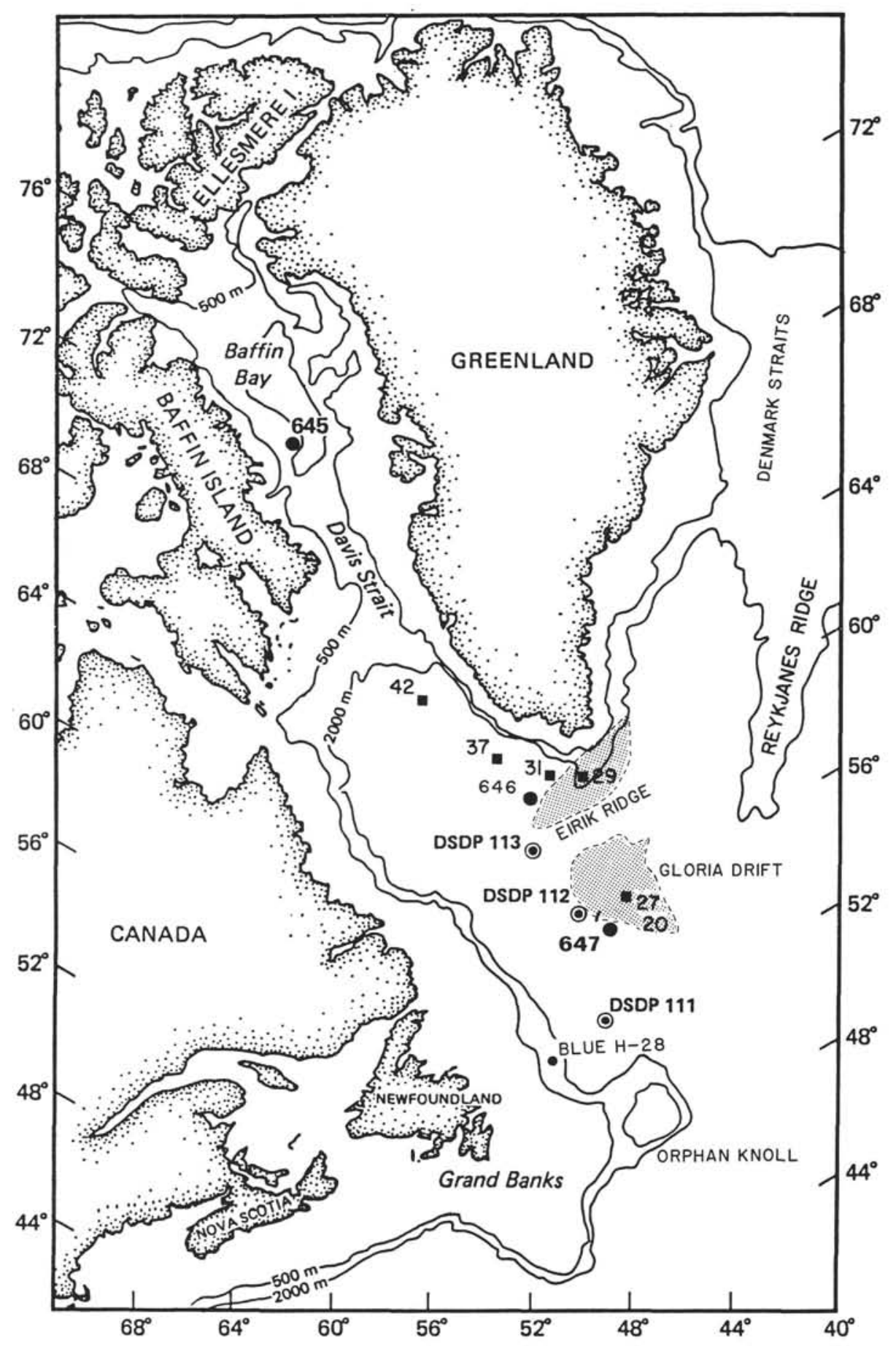

Figure 1. Location map for Baffin Bay and Labrador Sea showing the DSDP (circled dots), ODP sites (solid circles), and Hudson cores (solid squares) discussed by Fillon et al. (1981).

tures of pure carbonate to obtain linear curves to which unknown samples ( $1 \mathrm{~g}$ dry weight) were compared. Accuracy was $\pm 5 \%$.

\section{BOTTOM TOPOGRAPHY AND LITHOFACIES CORRELATION}

Site 647 is on the southern margin of the Gloria Drift, about $20 \mathrm{~km}$ east of the NAMOC (North Atlantic Mid-Ocean Channel) levee (Fig. 1). Echo profiles for this area show that below the 3900-m isobath, surficial sediments are mostly flat-lying and have acoustic features similar to levee overspill turbidites
(Type IB-1 of Chough et al., 1985). Cores 84-030-001, -002, and -003 are from the center of the survey area, in a water depth of between 3800 and $3770 \mathrm{~m}$. Surficial sediments here have acoustic features typical of low-energy contourites (Type IB-4, Chough et al., 1985), interfingered with pelagic and hemipelagic sediment. At core Sites $84-030-001$ and -002 , bottom topography is slightly undulating and has sediment waves less than $1 \mathrm{~m}$ high, spaced more than $2 \mathrm{~km}$ apart. Core $84-030-003$ is from a drift crest about $10 \mathrm{~m}$ upslope; here, crests are typically $20 \mathrm{~m}$ high and traces of climbing waves are evident. North and east of the ODP core sites and DSDP Site 112, large-scale climbing waves 
and dunes with crests of about $100 \mathrm{~m}$ and wavelengths of about $3 \mathrm{~km}$ occur in areas above the $3600-\mathrm{m}$ isobath. Cores V27-20 and V23-23, cited as reference sections for the western North Atlantic (Ruddiman and McIntyre, 1981; 1984), are located in this area of large-scale drift topography (Fig. 1).

Site 646 is located on the western flank of the Eirik Ridge, about $30 \mathrm{~km}$ north of DSDP Site 113 (Fig. 1). Echo profiles throughout the survey area show smooth, rolling bottom waves, with crest heights decreasing from about $15 \mathrm{~m}$ above the $3300-\mathrm{m}$ isobath (Core $84-030-004)$ to $10 \mathrm{~m}$ or less at $3400 \mathrm{~m}$. The surficial sediments in this area have acoustic features similar to the low-energy contourites at Site 647 (Chough et al., 1985). The more widely spaced crest and "softer" surface characteristics, however, suggest a lower energy environment, presumably due to the location of Site 646 in the lee of the Eirik Ridge. Sediment draping may also result from sporadic downslope transport from slump blocks observed on profiles above the $3150-\mathrm{m}$ isobath, near the location of Cores HU-75-30 and -31, which were used as standard references by Fillon and Duplessy (1980). Core HU-75-37 (Fillon and Duplessy, 1980; de Vernal and Hillaire-Marcel, 1987a) from a water depth of $3208 \mathrm{~m}$ north of Site 646, however, appears to be similar to Cores 84-030-004 and 84030-006 (Aksu et al., in press). Cores 84-030-004 and -006 contain more gravel in the glacial unit, however, which suggests a more proximal ice position or greater meltout of ice-rafted debris (IRD) in the site survey area.

Site 645 (about $1630 \mathrm{~m}$ water depth) and the site-survey Core $85-027-016(2091 \mathrm{~m})$ are located at the base of the steep-sided continental slope of central western Baffin Bay (Fig. 1). Highresolution Huntec acoustic profiles show that surface sediments $(0-20 \mathrm{~m})$ below the $2000-\mathrm{m}$ isobath are flat-lying and have strong continuous parallel sub-bottom reflectors and occasional packages of transparent sediments at apparent depths of $\sim 5-10$ mbsf (Fig. 2). Echo profiles show surficial sediments with acoustic characteristics of distal turbidites in the vicinity of Core 85027-016 (2091 m water depth), and slump deposits just above Site 645 ( $1630 \mathrm{~m}$ water depth). Large-scale scour and slump features are evident between the $1560-$ and $600-\mathrm{m}$ isobaths. Shallower slope areas (from 602 to $135 \mathrm{~m}$ water depth) show hummocky ice scour features and ice debris deposits.

Figure 3 summarizes the lithofacies distribution and correlation between the cores from the subarctic Labrador Sea, Sites 646 and 647. Facies C (Fig. 3) consists of brown (10 YR 6/4) or grayish brown (2.5 YR 5/2) calcareous hemipelagic muds (subfacies $\mathrm{C} 2$ in Figs. 4 and 5$)$ and thin $(<20 \mathrm{~cm})$ beds of muddy foraminiferal ooze (subfacies $\mathrm{Cl}$ ). The brown carbonate lithofacies alternate with thick beds $(\sim 100 \mathrm{~cm})$ of olive gray to dark gray (5 Y 5/2-5/1) or greenish gray (5GY 4/1) mud that comprise lithofacies B and D. These grayish sediments contain variable amounts of detrital and biogenic carbonate. Facies D is a greenish to olive gray mud (5GY 4/2) having more than $20 \%$ biogenic carbonate. At Site 646, this lithofacies also contains abundant biosiliceous sediments (diatoms and radiolarians). The gray facies B contains about 5\%-20\% biogenic carbonate and often includes abundant coarse-grained ice-rafted detritus (sand/gravel). Occasional thin beds of reddish brown (10 YR 6/3 to 7.5 YR $5 / 2$ ) silty mud can be correlated among the cores (lithofacies A) at Site 647; these red sediments may be correlated with facies group A red terrigenous sediments found in cores from the Newfoundland Basin and Grand Banks (Alam and Piper, 1981; Alam et al., 1983). The cores at Sites 646 and 645 also contain conspicuous thin $(<1 \mathrm{~cm})$ white bands (Unit F) that correspond to detrital carbonate layers.

Figure 4 shows the lithology of Core 85-027-016 from 2091 $\mathrm{m}$ on the western Baffin Bay Rise near Site 645. Sediments throughout this core are dominated by deposits of coarse-grained IRD that are typical of all glacial marine environments in Arctic regions, regardless of the extent and thickness of sea ice. Thus, these glacial marine deposits cannot be correlated easily with sediments from the subarctic waters of the Labrador Sea, including Davis Strait (Aksu and Mudie, 1985). Lithofacies in 26 cores from the northern slope and central basin of Baffin Bay, however, are defined and correlated stratigraphically (Aksu, 1985), and this system is used here to delineate sediment units in Cores 85-027-016 TWC and PC.

The glaciomarine sediment facies A and B (Fig. 4) are predominantly hemipelagic muds that contain large amounts of IRD and little biogenic sediment and lack bioturbation structures. Facies A consists of yellowish brown gravelly/sandy muds having a high $(20 \%-60 \%)$ detrital carbonate content. Pebble petrology, clay mineralogy (Aksu, 1985), and reworked palynomorphs (Mudie and Short, 1985) indicate that the main sources of IRD in Facies A are Paleozoic limestones and dolostones of the eastern Canadian Arctic Islands. Subfacies A2 consists of massive $(10-60 \mathrm{~cm})$ gravelly muds that fine upward to sandy or muddy beds with pebbles. Subfacies A4 includes sand/silt laminae that often grade to olive gray mud bands. Facies B consists of reddish, gravelly, sandy muds having a relatively low detrital carbonate content; the detrital component is mainly derived from Mesozoic-Paleogene siliclastic rocks in the Lancaster Sound-Bylot Island area. Subfacies B2 is a grayish red graded mud; subfacies B3 is a sandy mud containing grayish brown mud clasts; and subfacies B4 is a dark red mud with light and dark brown mud clasts.

Facies C, D, and F of the Baffin Bay series are primarily gravity flow deposits. Facies $\mathrm{C}$ is a dark olive, blackish, gravelly, sandy mud having a low detrital and biogenic carbonate content, which probably represents proximal turbidite beds. Subfacies D1 consists of olive gray muds containing well-graded sand and silt couplets that are probably turbidite deposits. Subfacies F5 is a brownish mud with chaotic bedding and is typically deposited from debris flows. Facies $\mathrm{E}$ consists of bioturbated hemipelagic muds having a relatively high biogenic content and usually containing $<20 \%$ IRD. Subfacies E1 is a brown diatom-rich mud; E2 is an olive gray to dark greenish gray mud with a relatively high foraminiferal content.

\section{RESULTS}

\section{Core 85-027-16 TWC and PC (Site 645, Baffin Bay)}

\section{Total Carbonate}

This appears to be the most useful parameter for correlation of cores in Baffin Bay. Large-scale cyclical fluctuations (5\% to $90 \%$ total carbonate) are evident (Fig. 4). Intervals of low carbonate are generally dominated by dolomite, while large carbonate peaks are mostly calcite. Dolomite content is relatively high throughout this core (5\%-20\%), compared to typical North Atlantic deep-sea cores, which usually contain less than 5\% (see Sites 646 and 647). Carbonate records in the TWC and PC cannot be matched exactly but the bottom of the TWC appears to approach the top of the PC, i.e., the surface $1.5 \mathrm{~m}$ is missing from the piston core. Thus, the total section recovered is about $10.30 \mathrm{~m}$. Two ${ }^{14} \mathrm{C}$ dates were obtained: one at $55 \mathrm{~cm}$ in the TWC $(10,590 \pm 1590$, RIDDL 638$)$ and one at $63 \mathrm{~cm}$ in the PC $(16,300 \pm 1260$, Beta 15493). These dates were taken only on separated foraminifers to avoid contamination by paleozoic carbonates.

\section{Stable Isotopes}

Isotopic values were obtained from this core on the plankotonic foraminiferal species, $N$. pachyderma(s), and data are reported in Hillaire-Marcel et al. (this volume). This record is discontinuous because of the intervals lacking calcareous foramini- 


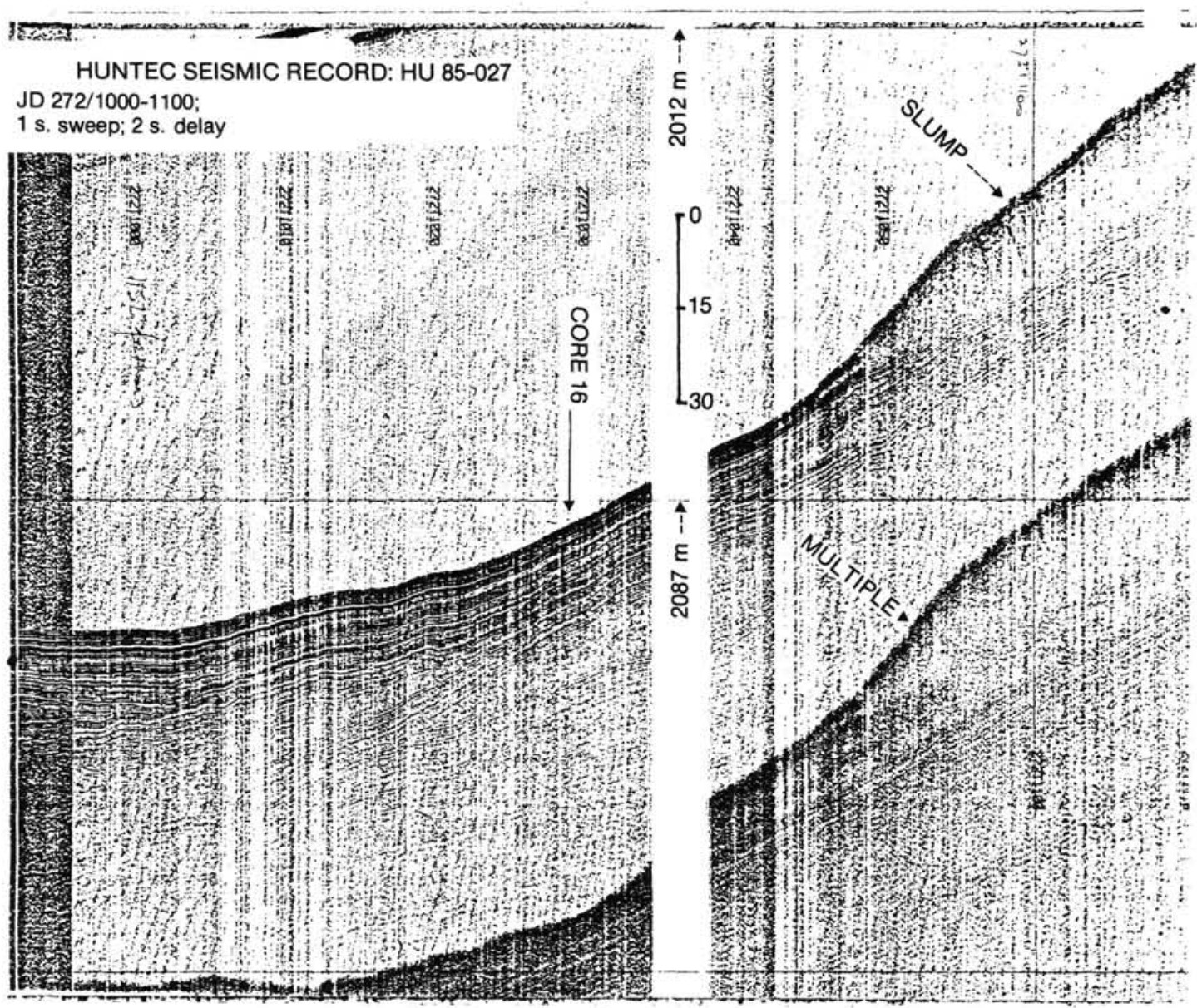

Figure 2. High-resolution Huntec seismic-reflection profile for Baffin Bay margin, showing the location of Core 85027-016 and main lithostratigraphic features.

fers. Values throughout the core range from +1.24 to $+4.18 \%$, with lightest values in the upper $30 \mathrm{~cm}$ and a range from +2.25 to $4.18 \%$ in the rest of the core. This isotope curve cannot be compared directly with other deep-sea records, but the base of the core may include the upper part of isotope stage 5 , based on the stable isotopes and the planktonic/benthic $(\mathrm{P} / \mathrm{B})$ ratios.

${ }^{13} \mathrm{C} /{ }^{12} \mathrm{C}$ ratios vary between -1.17 and $+0.57 \%$. The carbon curve roughly follows the oxygen curve, with lighter oxygen values generally corresponding to more negative ${ }^{13} \mathrm{C} /{ }^{12} \mathrm{C}$ values.

\section{Planktonic Foraminifers}

These were not differentiated quantitatively on the basis of species, but the assemblages were almost all dominated by Neogloboquadrina pachyderma (s). The most conspicuous aspect of the planktonic foraminifers was the fluctuation in total numbers (Fig. 4). Unlike hemipelagic sediments at most deep-sea sites, the $\mathrm{P} / \mathrm{B}$ ratio is low, usually about $1: 1$, in the upper $6 \mathrm{~m}$ of the $\mathrm{PC}$ and in all of the TWC. Below $6 \mathrm{~m}$ there are some intervals where the $\mathrm{P} / \mathrm{B}$ ratio exceeds $5: 1$, but it never reaches the values of North Atlantic deep-sea sediments. P/B ratios of about 1:1, however, are typically found in Arctic Ocean sediments (Scott et al., 1988).

\section{Benthic Foraminifers}

Benthic foraminifers occur in cycles that closely correlate with the carbonate fluctuations. Total numbers of specimens/ $10 \mathrm{~cm}^{3}$ vary from 0 to 10,640 (Table 1 and Fig. 5). Lowest num- bers are usually associated with peak carbonate values, with highest numbers just above peak carbonate levels, where carbonate is still relatively high because the detrital carbonate of the debris flow has not been buried yet. One sees these changes with difficulty in Figure 4 because the scale of the change is so small. Table 1 has more precise information. One notable exception to this is at $303 \mathrm{~cm}$, where the highest carbonate value as well as the highest numbers of foraminifers are recorded (Table 1 and Fig. 4).

The relative abundances of dominant species change throughout the core. Stetsonia horvathi most often predominates, but large peaks of Cassidulina laevigata, Buliminella hensoni, Islandiella terestis, Triloculina trihedra, and Cassidulina reniforme also occur. Agglutinated species dominate the intervals that lack calcite (e.g., Fig. 5, surface, $334 \mathrm{~cm}, 461 \mathrm{~cm}$ ). A typical cycle in this core sequence occurs as follows: intervals of peak carbonate, few or no foraminifers (e.g., at $501 \mathrm{~cm}$ ), are succeeded by slightly lower carbonate and high numbers of calcareous foraminifers $(481 \mathrm{~cm})$, followed by an interval of low total carbonate, high percentage of dolomite, and a peak in agglutinated foraminifers $(461 \mathrm{~cm})$. This type of cycle occurs in whole or in part throughout the core. The high carbonate sequence with sparse faunas almost always contains reworked shallow-water forms (Cassidulina reniforme); the high numbers of faunas are usually dominated by $S$. horvathi or B. hensoni, and the agglutinated sequences contain inner linings of Rhizammina algaeformis. 


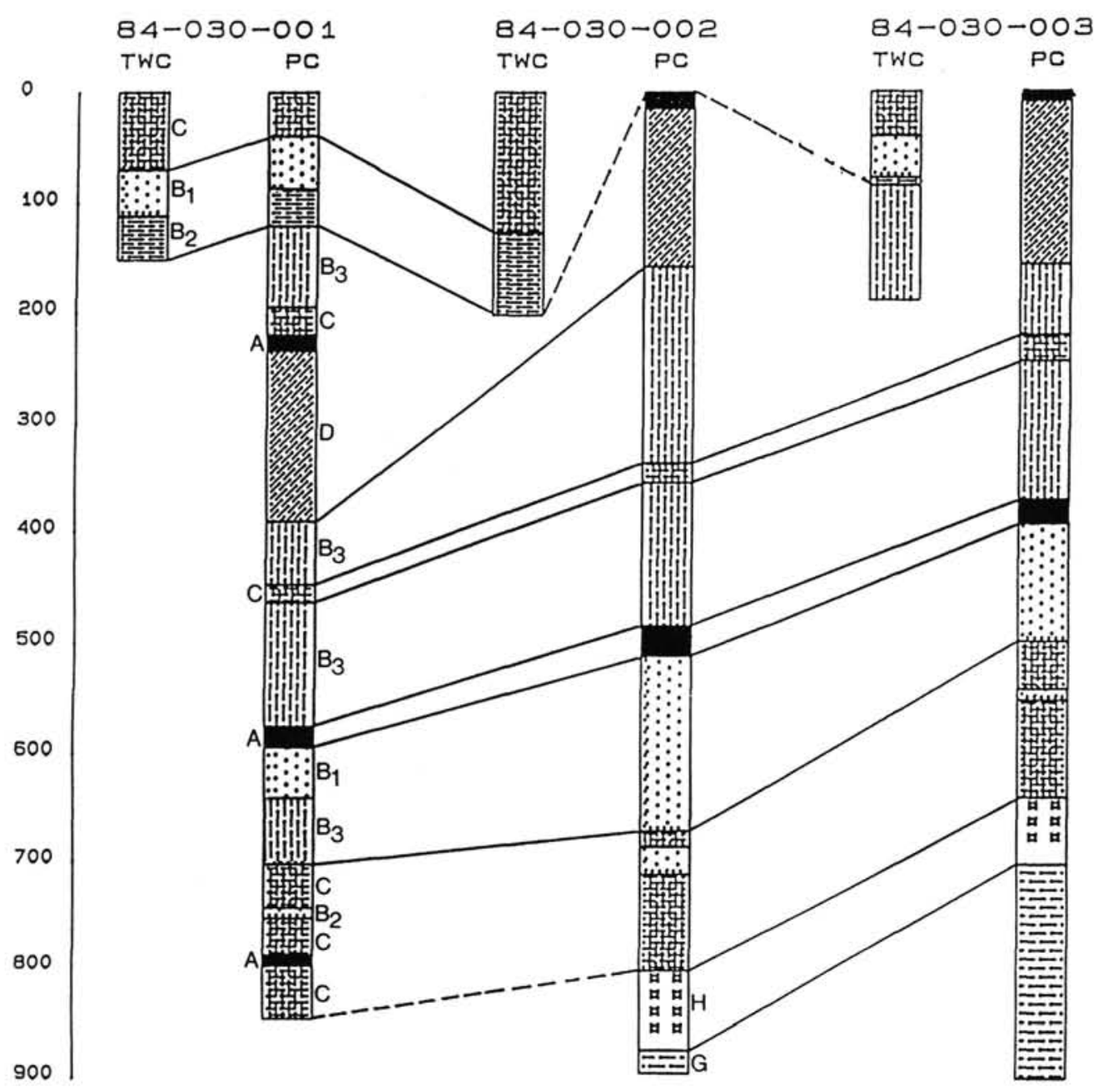




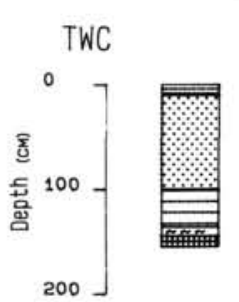

PC

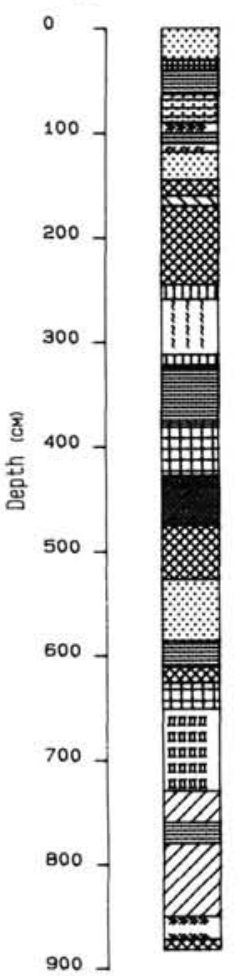

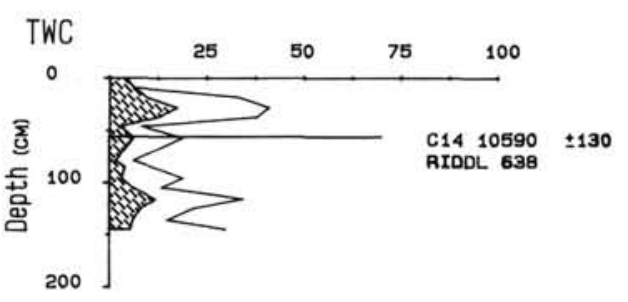
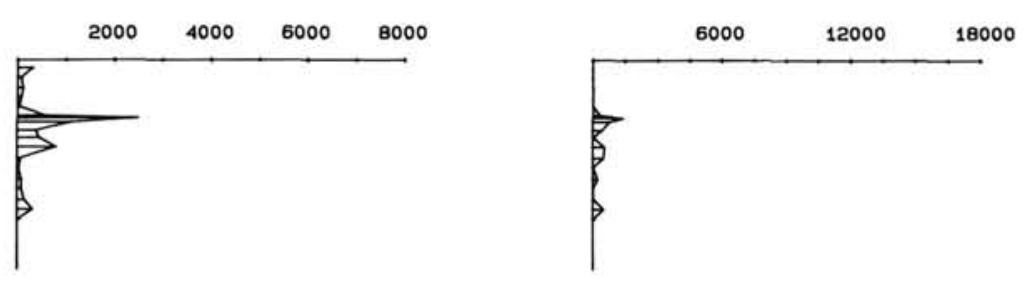

PC
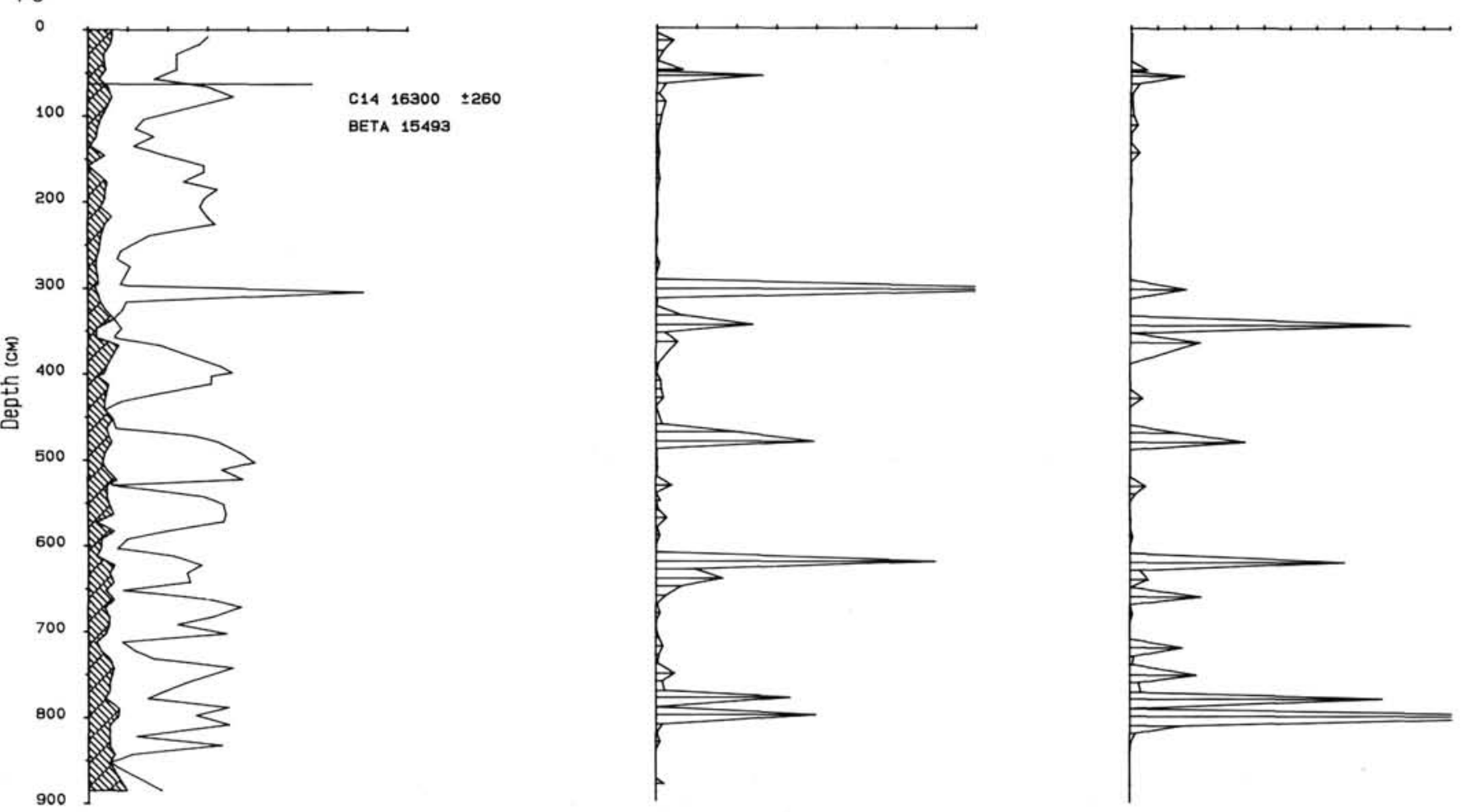

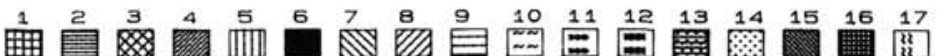

Figure 4. Lithofacies, total carbonate, and total numbers of planktonic and benthic foraminifers from Baffin Bay Core 85-027-016 TWC and PC. Stippled area on the carbonate curve is dolomite. Lithologic facies from text: Facies A, yellowish brown sandy/gravelly muds with detrital carbonate IRD; Facies B, reddish gravelly sandy muds with siliclastic IRD; Facies $\mathrm{C}$, dark olive/blackish gravelly/sandy turbidites; Facies D, brown muddy turbidites; Facies E, bioturbated hemipelagic muds; Facies F, brownish debris flow deposits. These facies are listed with the following lithologic symbols for reference to the figure. Lithologic symbols: 1) fine gravel-A; 2) clay-E; 3) silt-A; 4) sand-fine gravel-gravel-C; 5) gravel-B; 6) sand-B; 7) sand-A; 8) sand-silt-A; 9) sand-silt-D; 10) AW-carbonate; 11) pebbles-C; 12) sand-silt-fine gravel-D; 13) gravel-A-B; 14) sand-gravel-A; 15) fine gravel-sand-A; 16) sand-mud-B; and 17) clayey mud-F. 
mined from ${ }^{18} \mathrm{O} /{ }^{16} \mathrm{O}$ and palynological data from Core 84-030006 (Aksu et al., in press) at Site 646 and Core HU-75-37 north of the site survey area (de Vernal, 1986).

\section{Core 84-030-001 TWC and PC (Site 647, Labrador Sea)}

\section{Total Carbonate}

The carbonate curve (Fig. 8) shows a classic profile for North Atlantic deep-sea sediments, with high $\mathrm{CaCO}_{3}$ marking interglacial intervals and low $\mathrm{CaCO}_{3}$ in glacial stages. Dolomite is low throughout $(<5 \%)$. The $\mathrm{CaCO}_{3}$ fluctuations closely follow the oxygen isotope curve and are usually inversely related to $\delta^{13} \mathrm{C}$ values (Fig. 8). The surface of the PC appears to be the same as about $1 \mathrm{~m}$ in the TWC, i.e., the Holocene and late Wisconsinan sediments are not recorded in the PC.

\section{Stable Isotopes}

This oxygen-isotope curve is similar to the one from Core 84030-003 (de Vernal and Hillaire-Marcel, 1987b) and can be compared directly with other North Atlantic sites (Figs. 8 and 9). The isotope curve closely follows the total carbonate curve with stage $1(0-25 \mathrm{~cm}$ in the TWC), stage $2(25-100 \mathrm{~cm}$ in the TWC), stage $3(100-153 \mathrm{~cm}$ in the TWC, $0-150 \mathrm{~cm}$ in the PC), stage 4 (150-190 cm in PC), stage $5(190-460 \mathrm{~cm})$, stage $6(460-700$ $\mathrm{cm})$, and stage $7(700-860 \mathrm{~cm})$. The magnitude of change and shape of the curve is similar to the Site 646 values and other North Atlantic records; most of the substages within stages 5 and 7 are evident (Fig. 8).

\section{Planktonic Foraminifers}

Because this site was deemed of highest importance from the standpoint of paleoceanography, we also studied the planktonic foraminiferal assemblages in Core 84-030-001 (Fig. 8), although only $N$. pachyderma (sinistral and dextral) and subarctic species as a group are differentiated. As expected, peak abundances of subarctic species occur in stage $1(0-20 \mathrm{~cm}$, TWC), stage $5 \mathrm{a}$ $(200-210 \mathrm{~cm})$, stage $5 \mathrm{e}(400-450 \mathrm{~cm})$, stage 7 a $(750-775 \mathrm{~cm})$, and stage $7 \mathrm{c}(825-850 \mathrm{~cm})$. These occurrences of warm-water indicators confirm our interpretation of the isotopic curve; they are further supported by palynological data (de Vernal, 1986; Aksu et al., in press).

\section{Benthic Foraminifers}

Total numbers in this core vary $\left(21-1930 / 10 \mathrm{~cm}^{3}\right)$ and show the same correlation with carbonate as those observed at Site 646 , with high numbers corresponding to carbonate peaks.

The surface assemblage ( $0-20 \mathrm{~cm}$, TWC) is co-dominated by Nuttallides umbonifera and Epistominella exigua. In the interval $(21-51 \mathrm{~cm})$ below this, numbers of foraminifers decrease and Uvigerina peregrina together with Pullenia subcarinata dominates (Table 3, back-pocket foldout, and Fig. 5). At about $60 \mathrm{~cm}$ (TWC), Triloculina trihedra also becomes common, and variations of this assemblage occur down to $260 \mathrm{~cm}$, where $N$. umbonifera again becomes prominent. At $280 \mathrm{~cm}$ Stetsonia horvathi becomes common and persists to $390 \mathrm{~cm}$. The faunas at 60-390 $\mathrm{cm}$ correspond to isotopic stages 2 through 4 . From 390 to 460 $\mathrm{cm}$ the surface (Holocene) assemblage reoccurs, and numbers of foraminifers are higher. This interval corresponds to isotopic stage 5 . The glacial/interstadial stages 2 through 4 assemblages do not reoccur below stage 5 (i.e., no $U$. peregrina zones), and $N$. umbonifera and $E$. exigua are replaced by lower numbers of $P$. subcarinata and $T$. trihedra. Stetsonia horvathi is common throughout the lower part of the core.

\section{DISCUSSION}

\section{General}

The most obvious characteristic that emerges from both the piston cores and the ODP holes (Kaminski et al., this volume) is that none of the benthic faunas at the three Leg 105 sites are closely comparable. The two Labrador Sea sites record differences in the interglacial bottom-water masses, which probably reflect the different water depths at the two sites. The carbonate record for the Labrador Sea sites is similar, however, suggesting closely related histories of plankton productivity and detrital carbonate influx, but Site 646 lacks the distinctive lower Pleistocene planktonic marker species that are prominent in Site 647 (Kaminski et al., this volume). The paleoecological record for Baffin Bay (Site 645, Core 85-027-16 TWC and PC) does not compare closely to that in cores from outside the central Baffin Bay basin (see also de Vernal et al., 1987; de Vernal and Mudie, this volume). Sedimentation at Site 645 appears to be dominated by episodic events, not paleoceanographic changes. This contrasts with previous reports of a compressed late Quaternary isotopic record in the central, deep basin of Baffin Bay (e.g., Aksu, 1983, 1985). Based on high-resolution seismics from the 85-027 cruise, most probably no compressed Quaternary record occurs anywhere in the central basin of Baffin Bay.

\section{Total Carbonate}

Total carbonate for the two Labrador Sea piston cores follows a typical deep-sea pattern, with high biogenic carbonate during interglacials and lower carbonate (i.e., lower productivity) during glacial cycles. In Cores 84-030-01 and -04, the carbonate and oxygen-isotope records are almost interchangeable. There is also an almost continuous low influx of dolomite, which suggests low influx of ice-rafted or turbidite sediments during both glacial and interglacial intervals.

In contrast, the Baffin Bay core contains a total carbonate record that is almost inversely related to that found in most North Atlantic Ocean areas. Either low or no calcitic carbonate was observed in the Holocene sediments, and a series of highcarbonate layers, representing ice-rafted detritus and debris flows, characterize the last glaciation. In central Baffin Bay, the highcarbonate layers are largely of detrital origin and are derived from the Paleozoic carbonates on Baffin Island (Jacobs et al., 1985), in contrast to the biogenic carbonate that dominates in the Labrador Sea and North Atlantic records. The high sedimentation rates resulting from these ice-rafted detritus and debris flows are reflected in the low numbers of foraminifers in peak carbonate intervals (Fig. 4 and Table 1). The only interval that can be clearly identified as an interglacial event is the surface $20 \mathrm{~cm}$ of the TWC where calcitic carbonate is absent and only agglutinated benthic foraminifers resistant to dissolution are present (Figs. 4 and 5). Apparently, the modern bottom water in Baffin Bay is too corrosive to allow carbonate preservation without the massive influxes of detrital carbonate that occurred during glacial intervals. Also during glaciations, when Baffin Bay was presumably covered with perennial sea ice, there may have been bottom water generation similar to that in the modern Arctic Ocean, where high-salinity water is produced on the arctic continental shelves and sinks into the deep arctic basins (Aagaard et al., 1985). Today's Arctic Ocean has noncorrosive bottom water.

\section{Stable Isotopes}

Stable-isotope data presented here are from Cores 84-030001 (near Site 647) and -004 (near Site 646), and isotopic data are reported for the Baffin Bay core discussed by Hillaire-Marcel et al. (this volume). However, Core 84-030-001 (near Site 647 ) is the only one of these that extended past stage 5. The data from Core 84-030-001 link the high-resolution stratigraphy from Pleistocene sediments in Hole 647B with the recent sediments recovered at the surface of Core 84-030-001 TWC. Given that the Holocene sediment is only $20 \mathrm{~cm}$ thick in the TWC, it probably was not recovered by the hydraulic piston corer. In fact, our preliminary examination of high-resolution samples from Hole 

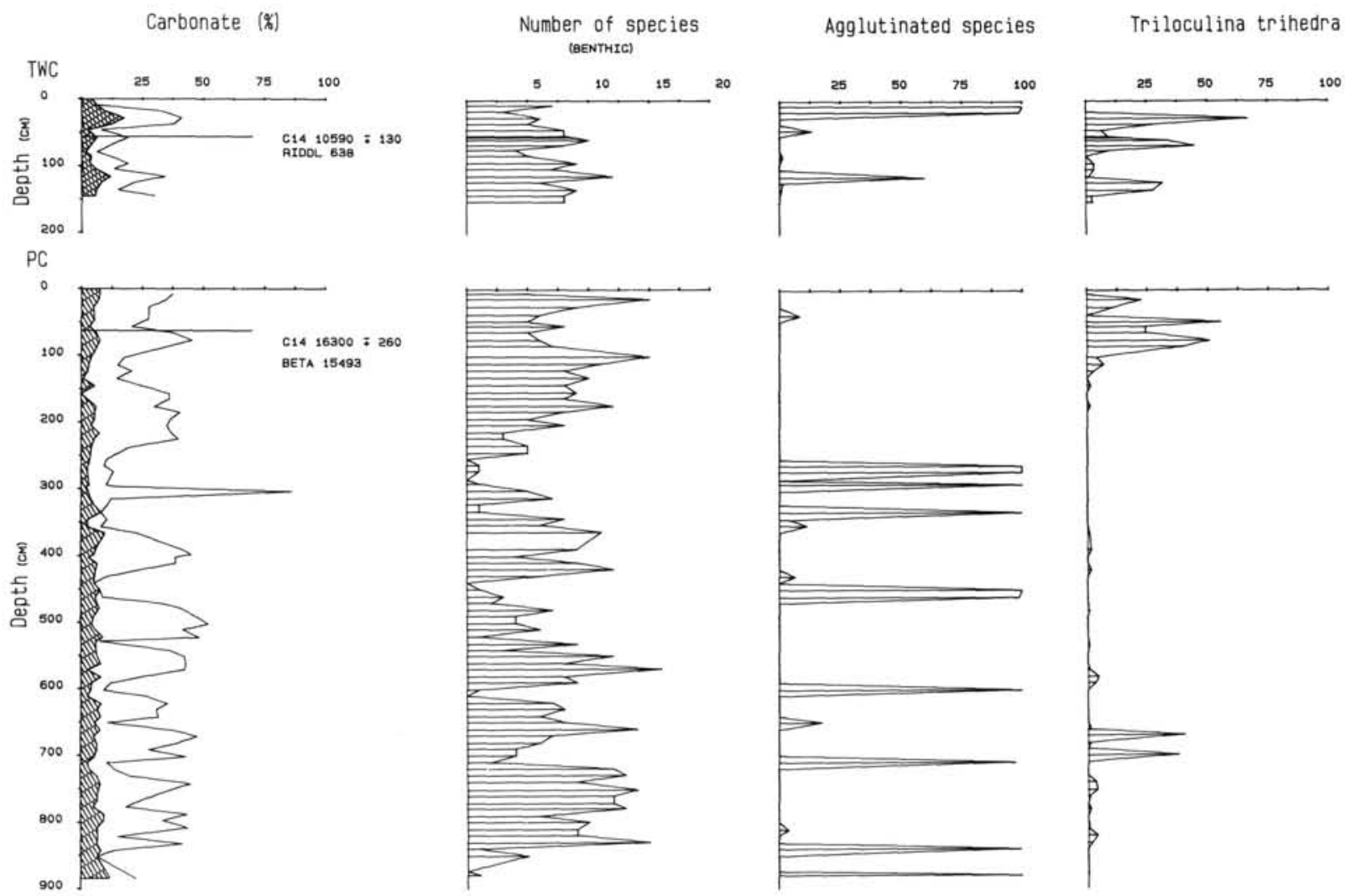

Figure 5. Total carbonate vs. percentage occurrences of various benthic foraminifers in Baffin Bay Core 85-027-016 TWC and PC.

647B indicates that the top of Hole 647B corresponds to isotope stage 2 or 3 . Hence, the site-survey core data provide an essential link required to interpret completely the high-resolution record from Hole 647B.

Interpretation of the stable-isotope record from Baffin Bay (Hillaire-Marcel et al., this volume) is interesting because the lightest oxygen-isotope values appear to correspond with high detrital carbonate layers, which suggests meltwater events in the surface water and subsequent meltout of IRD derived from northern Baffin Bay. Precise correlation is not possible because many of the high carbonate layers contain insufficient foraminifers for isotopic analysis. Note, however, that no oxygen-isotope values lower than $+1.00 \%$ were found, in contrast to negative values reported by Aksu (1983) for the same species in a neighboring core (HU-75-040). Clearly, the isotope curves from cores in central Baffin Bay cannot be correlated simply with cores from outside the confines of Baffin Basin.

\section{Benthic Foraminifers}

Assemblages of benthic foraminifers are different at all three sites. The difference between the faunas at the two Labrador Sea sites probably reflects the fact that the boundary between the Western Boundary Undercurrent (WBU) and the top of the North Atlantic Bottom Water (NABW) occurs in the water depth range that separates Sites 646 and 647 . This is clearly evident in the different Holocene faunas at the two sites, with Epistominella exigua dominating at Site 646 under the WBU and Nuttallides umbonifera dominating at Site 647 under the NABW.

In central Baffin Bay, the late Holocene fauna is similar to some abyssal faunas observed to the south on the Scotian Slope and Rise in water depths greater than $4500 \mathrm{~m}$ (e.g., Schroeder, 1986). However, the water depth at Site 645 is only $2000 \mathrm{~m}$; thus, the fauna clearly is not depth dependent. Studies of planktonic foraminifers in Baffin Bay show productivety to be high (Stehman, 1972), thus the carbonate-free environment reflects an unusually shallow carbonate compensation depth. Clearly, this condition does not persist throughout the late Quaternary because low carbonate units are relatively rare in Core 85-027-016. The calcareous fauna that occupies some segments of the core has direct affinities to Arctic Ocean modern faunas, which also have large populations of Stetsonia horvathi and Buliminella hensoni (Lagoe, 1977), together with low P/B ratios (Scott et al., 1988). The cycle of foraminiferal faunas described here is complex and depends on sedimentation rates, local bottom water production, and timing of low sedimentation intervals. During periods of seasonal ice cover, such as the present, no high-salinity local bottom water is produced, and the shallow sill $(<900 \mathrm{~m})$ at Davis Strait prevents North Atlantic deep water from entering Baffin Bay. Hence, the bottom water in Baffin Bay becomes corrosive and only agglutinated faunas occur, similar to the shallower parts of the Fram Basin in the Arctic Ocean (Scott et al., 1988). During periods of perennial ice cover, there is episodic glacial influx of carbonates; these carbonate peaks are low in foraminifers, but biogenic carbonate (i.e., benthic and planktonic foraminifers) forms just above these layers before the carbonate is buried by hemipelagic sedimentation. In addition, the high-salinity bottom water generated on the shelf during periods of perennial ice cover, similar to the present day Arctic Ocean, may promote carbonate preservation. The similarity to Arctic Ocean bottom water is supported by the Stetsonia faunas that are identical to Arctic Ocean faunas (Scott et al., 1988).

\section{SUMMARY}

The primary objective for studying these three site-survey piston cores was to provide a high-resolution framework to help 
Stetsonia horvathi
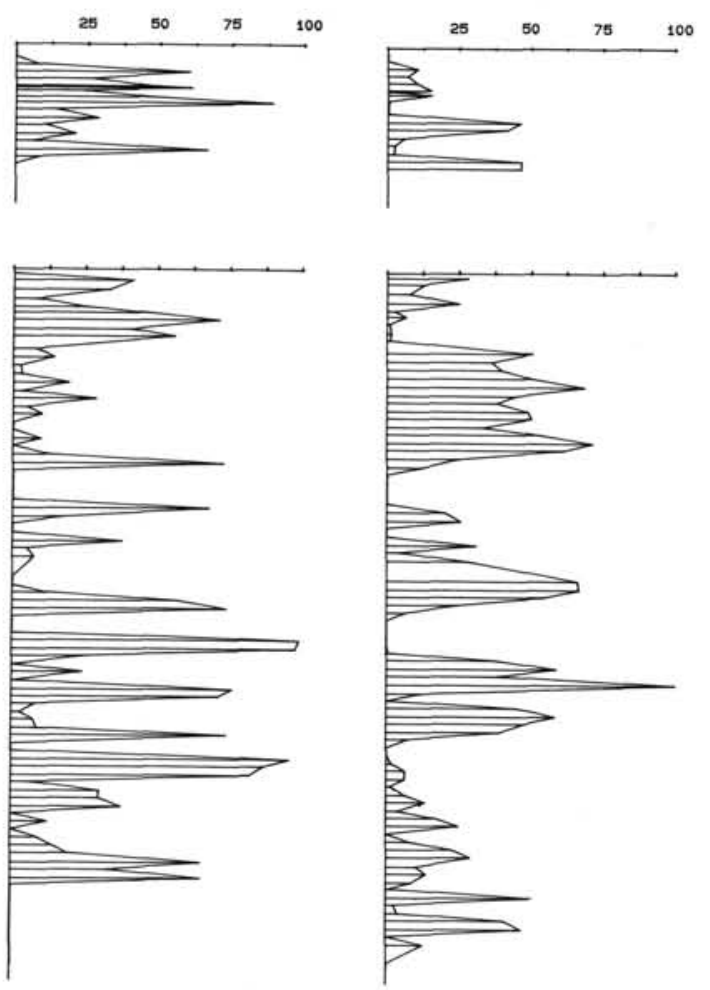

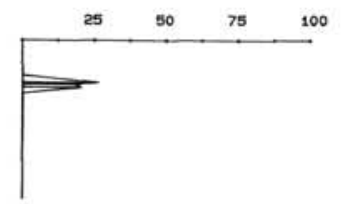

Cassidulina laevigata

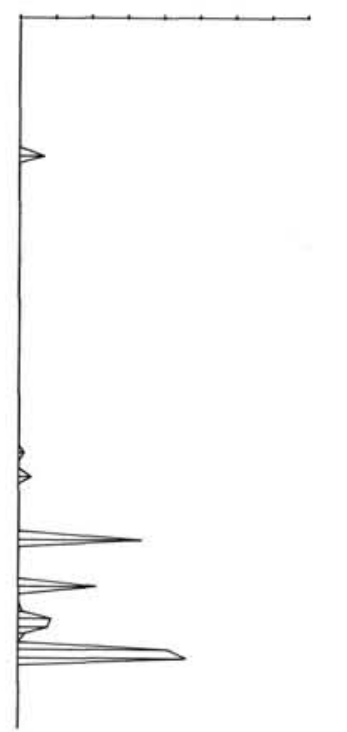

Buliminella hensoni

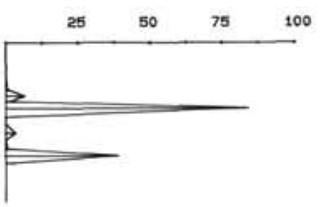

Islandiella teretis
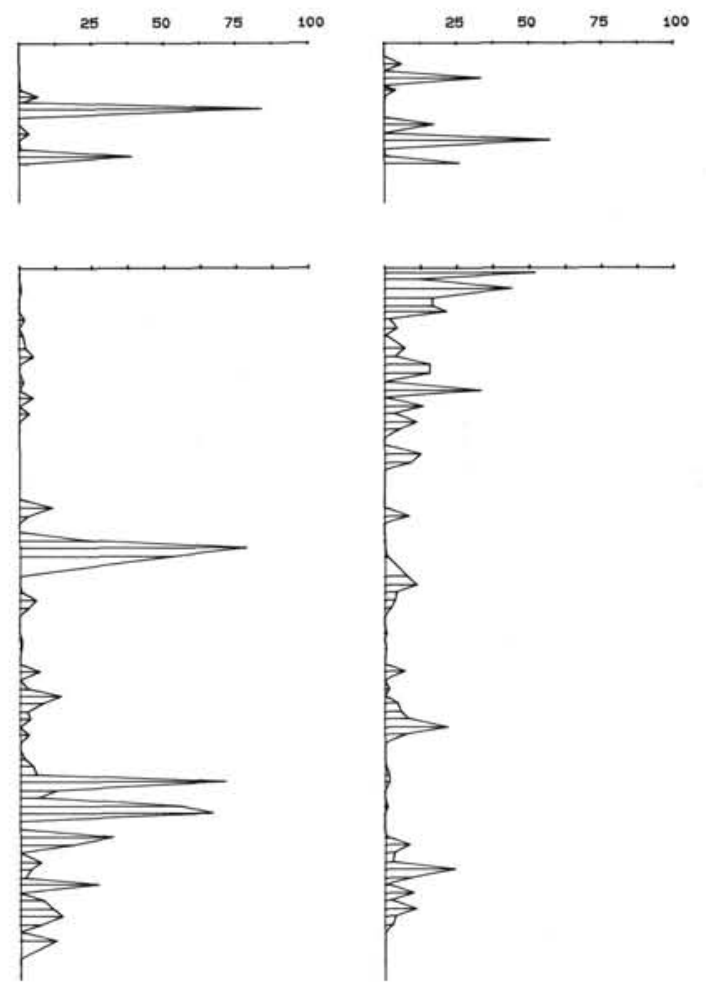

Figure 5 (continued).

interpret the ODP holes where high-resolution studies are sometimes impossible owing to limited sediment recovery by the HPC. These site-survey piston/trigger weight core combinations supply us with the true sediment/water interface sample that is usually not recovered, even with the advanced HPC.

The high resolution provided by the site-survey piston cores also illustrates that most of the changes observed from the lowresolution samples (Kaminski et al., this volume) in the Quaternary ODP sections are a function of the portion of a glacial/interglacial sequence from which the shipboard samples were taken, rather than having a definite biostratigraphic implication in terms of presence or absence of guide fossils.

\section{ACKNOWLEDGMENTS}

C. D. Younger, S. Walker, and L. Gajewska performed some of the selection and machine operation required for isotope results. F. Bulca did much of the drafting. J. Dabros and C. Schroeder assisted in collecting and describing some of the cores. The co-chief scientists of the two Hudson cruises, S. Srivastava and B. MacLean, kindly provided us access to the cores. Thanks also to the officers and crew of the Hudson for their assistance. Funding was provided by Natural Sciences and Engineering Research Council (NSERC, Canada) operating grants to Scott and Medioli, an NSERC Strategic grant to Scott, Mudie, Mayer, and Medioli, and support from the Geological Survey of Canada for Project 820044 (Mudie).

\section{REFERENCES}

Aagaard, K., Swift, J. H., and Carmack, E. C., 1985. Thermohaline circulation in the Arctic Mediterranean seas. J. Geophys. Res., 90(C3):4833-4846.

Aksu, A. E., 1983. Holocene and Pleistocene dissolution cycles in deepsea cores of Baffin Bay and Davis Strait: paleoceanographic implications. Mar. Geol., 53:331-348.

, 1985. Climatic and oceanographic changes over the past 400,000 years: evidence from deep-sea cores on Baffin Bay and
Davis Strait. In Andrews, J. T. (Ed.), Quaternary Environments, Eastern Canadian Arctic, Baffin Bay and Western Greenland: Boston (Allen and Unwin), 181-209.

Aksu, A. E., and Mudie, P. J., 1985. Late Quaternary stratigraphy and paleoecology of northwest Labrador Sea. Mar. Micropaleontol., 9: 537-557.

Aksu. A. E., Mudie, P. J., Macko, S. S., and de Vernal, A., in press. Upper Cenozoic history of the Labrador Sea, Baffin Bay and the Arctic Ocean: a paleoclimatic and paleoceanographic summary. $P a$ leoceanography.

Alam, M., and Piper, D.J.W., 1981. Detrital mineralogy and petrology of deep-water continental margin sediments off Newfoundland. Can. J. Earth Sci., 18:1336-1345.

Alam, M., Piper, D.J.W., and Cooke, H.B.S., 1983. Late Quaternary stratigraphy and paleoceanography of the Grand Banks continental margin, eastern Canada. Boreas, 12:253-261.

Andrews, J. T., Aksu, A., Kelly, M., Klassen, R., Miller, G. H., Mode, W. N., and Mudie P., 1985. Land/ocean correlations during the last interglacial/glacial transition, Baffin Bay, Northwestern North Atlantic: a review. Quat. Sci. Rev., 4:333-355.

Chough, S. K., Mosher, D. C., and Srivastava, S. P., 1985. Ocean Drilling Program (ODP) site survey (Hudson 84-030) in the Labrador Sea: $3.5 \mathrm{kHz}$ profiles. Geol. Surv. Can. Pap., 85-1B:33-41.

CLIMAP Project members, 1981. Seasonal recontructions of the Earth's surface at the last glacial maximum. Geol. Soc. Am. Map and Chart Series, MC-36:1-18.

Denton, G. H., and Hughes, T. J.(Eds.), 1981. The Last Great Ice Sheets: New York (John Wiley \& Sons).

de Vernal, A., 1986. Analyses palynologiques et isotopiques de sediments de la mer du Labrador et de la baie de Baffin: éléments d'une climatostratigraphie du Quaternaire supérieur dans l'est du Canada [Ph.D. dissert.]. Université de Montréal.

de Vernal, A., and Hillaire-Marcel, C., 1987a. Marginal paleoenvironments of the eastern Laurentide ice sheet and timing of the last ice maximum and retreat. Géograph. Phys. Quat., 41:265-277. ,1987b, Eléments d'une climatostraigraphie du Pleistocène moyen et supérieur dans l'est du Canada par l'analyse palynologi- 
que et isotopique du forage 84-030-003, mer du Labrador. Can. J. Earth Sci., 24:1886-1902.

de Vernal, A., Hillaire-Marcel, C., Aksu, A. E., and Mudie, P. J., 1987. Palynostratigraphy and chronostratigraphy of Baffin Bay deep-sea cores: climatostratigraphic implications. Palaeogeogr., Palaeoclimatol., Palaeoecol., 61:97-105.

Fillon, R. H., and Duplessy, J-C., 1980. Labrador Sea bio-, tephro-, oxygen isotope stratigraphy and late Quaternary paleographic trends. Can. J. Earth Sci., 17:831-854.

Fillon, R. H., Miller, G. H., and Andrews, J. T., 1981. Terrigenous sand in Labrador Sea hemipelagic sediments and paleoglacial events on Baffin Island over the last 100,000 years. Boreas, 10:107-124.

Gates, W. L., 1976. The numerical simulation of ice age climate with a global general circulation model. J. Atmos.. Sci., 33:1844-1873.

Jacobs, J. D., Andrews, J. T., and Funder, S., 1985. Environmental background. In Andrews, J. T. (Ed.), Quaternary Environments, Eastern Canadian Arctic, Baffin Bay and Western Greenland: Boston (Allen and Unwin), 26-68.

Lagoe, M. B., 1977. Recent benthic foraminifera from the central Arctic Ocean. J. Foramininiferal. Res., 7(2):106-129.

Mudie, P. J., and Aksu, A. E., 1984. Palaeoclimate of Baffin Bay from $300,000 \mathrm{yr}$ record of foraminifera, dinflagellates, and pollen. $\mathrm{Na}$ ture, 312(5995):630-634.

Mudie, P. J., and Short, S. K., 1985. Marine palynology of Baffin Bay. In Andrews, J. T. (Ed.), Quaternary Environments, Eastern Canadian Arctic, Baffin Bay and Western Greenland: Boston (Allen and Unwin), 263-308.

Mudie, P. J., Piper, D.J.W., Rideout, K., Robertson, K. R., Schafer, C. T., Vilks, G., and Hardy, I. A., 1984. Standard methods for col- lecting, describing and sampling Quaternary sediments at the Atlantic Geoscience Centre. Geol. Surv. Can. Open File, 1044:1-46.

Müller, G., and Gastner, M., 1971. The "Karbonate-Bombe," a simple device for the determination of the carbonate content in sediments, soils, and other materials. Neues Jahrb. Miner. Monatsh., 10:466469.

Ruddiman, W. F., and McIntyre, A., 1981. The North Atlantic Ocean during the lastdeglaciation. Palaeogeogr., Palaeoclimatol., Palaeoecol., 35:145-214.

1984. Ice-age thermal response and climatic role of the surface Atlantic Ocean, $40^{\circ} \mathrm{N}$ to $63^{\circ} \mathrm{N}$. Geol. Soc. Am. Bull., 95:381396.

Scott, D. B., Baki, V., Younger, C. D., Medioli, F. S., and Stehman, C., 1986. Empirical method for measuring seasonality in deep-sea cores. Geology, 14:643-646.

Scott, D. B., Mudie, P. J., Baki, V., MacKinnon, K. D., and Cole, F. E., 1989. Biostratigraphic and late Cenozoic paleoceanography in the Arctic Ocean: foraminiferal, lithostratigraphic, and isotopic evidence. Geol. Soc. Am. Bull., 101:260-277.

Schroeder, C. J., 1986. Deep-water arenaceous foraminifera in the northwest Atlantic Ocean. Can. Tech. Rept. Hydrogr. Ocean Sci., 71:1190.

Svrivastava, S. P., Arthur, M., et al., 1987. Proc. ODP, Init. Repts., 105: College Station, TX (Ocean Drilling Program).

Stehman, C. F., 1972. Planktonic foraminifera in Baffin Bay, Davis Strait and Labrador Sea. Marit. Sediments., 8(1):13-19.

Date of initial receipt: 27 May 1987

Date of acceptance: 24 May 1988

Ms B105-169

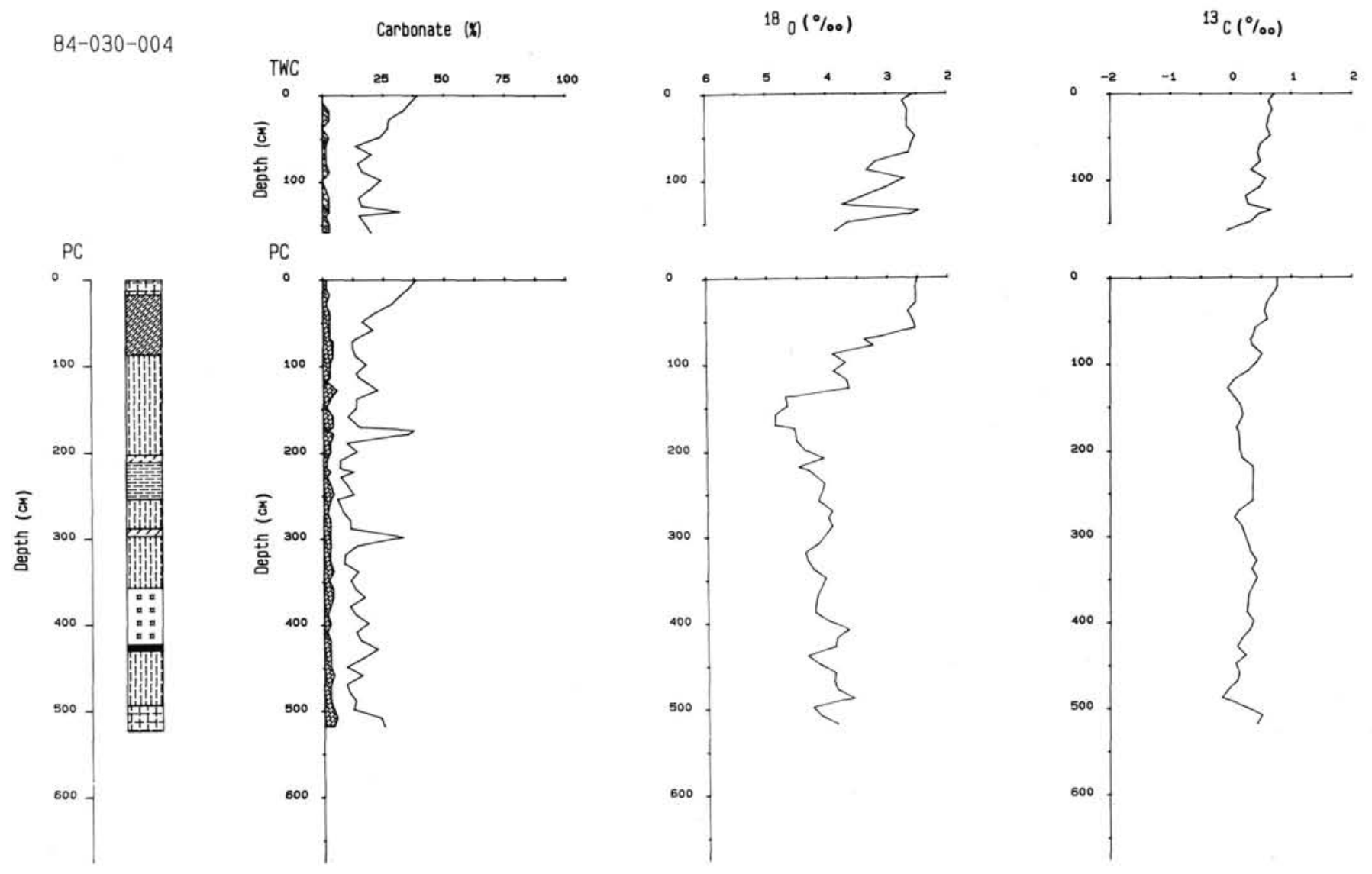

Figure 6. Lithofacies, stable isotopes, and total carbonate in Labrador Sea Core 84-030-04 TWC and PC. Note that the top of the TWC and PC are identical. Stippled area on carbonate curve is dolomite. 
84-030-004 PISTON AND GRAVITY CORES

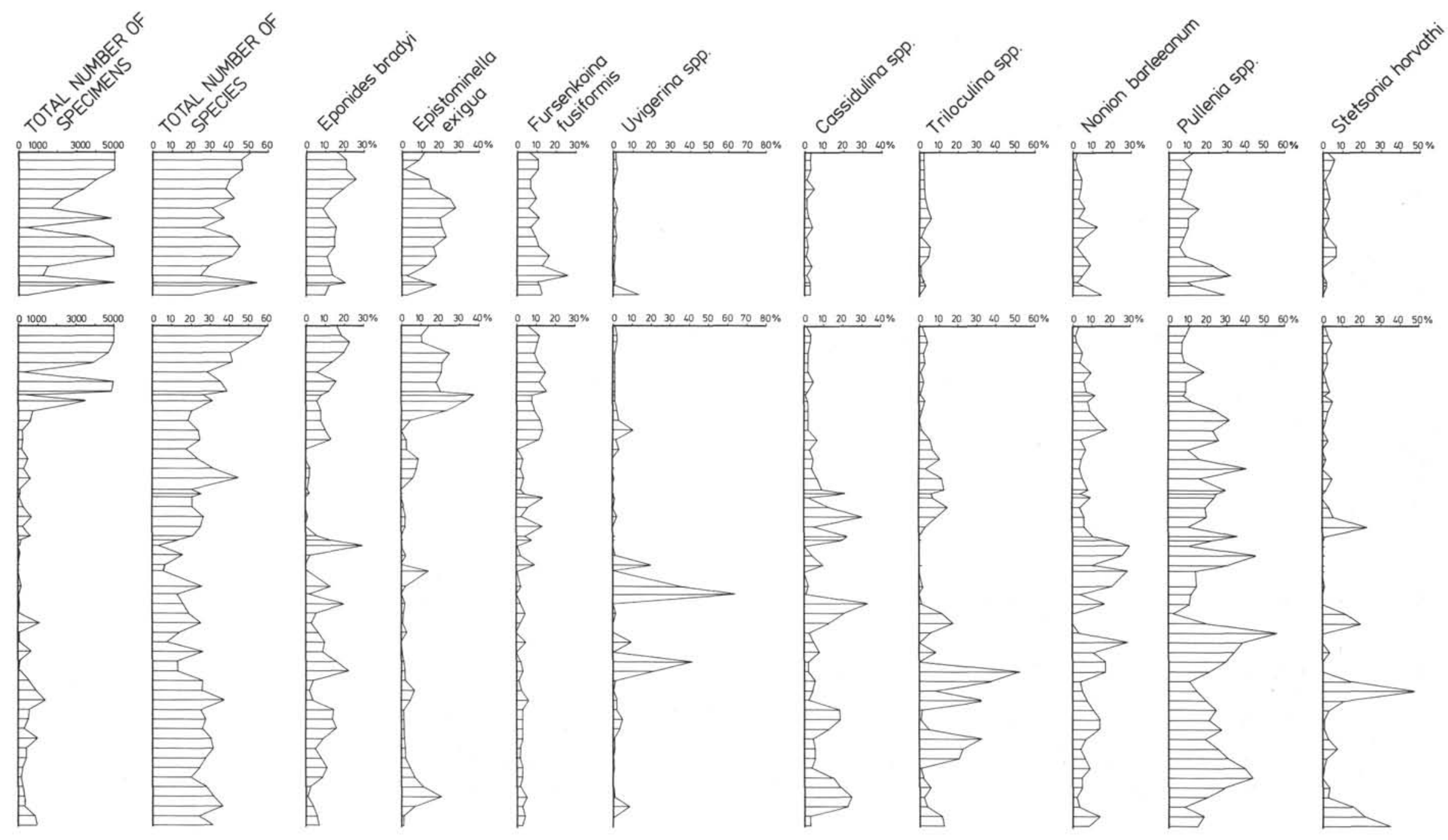


Table 1. Percentage occurrences of benthic foraminifers in Core 85-027-016 TWC and PC $(X<1 \%)$

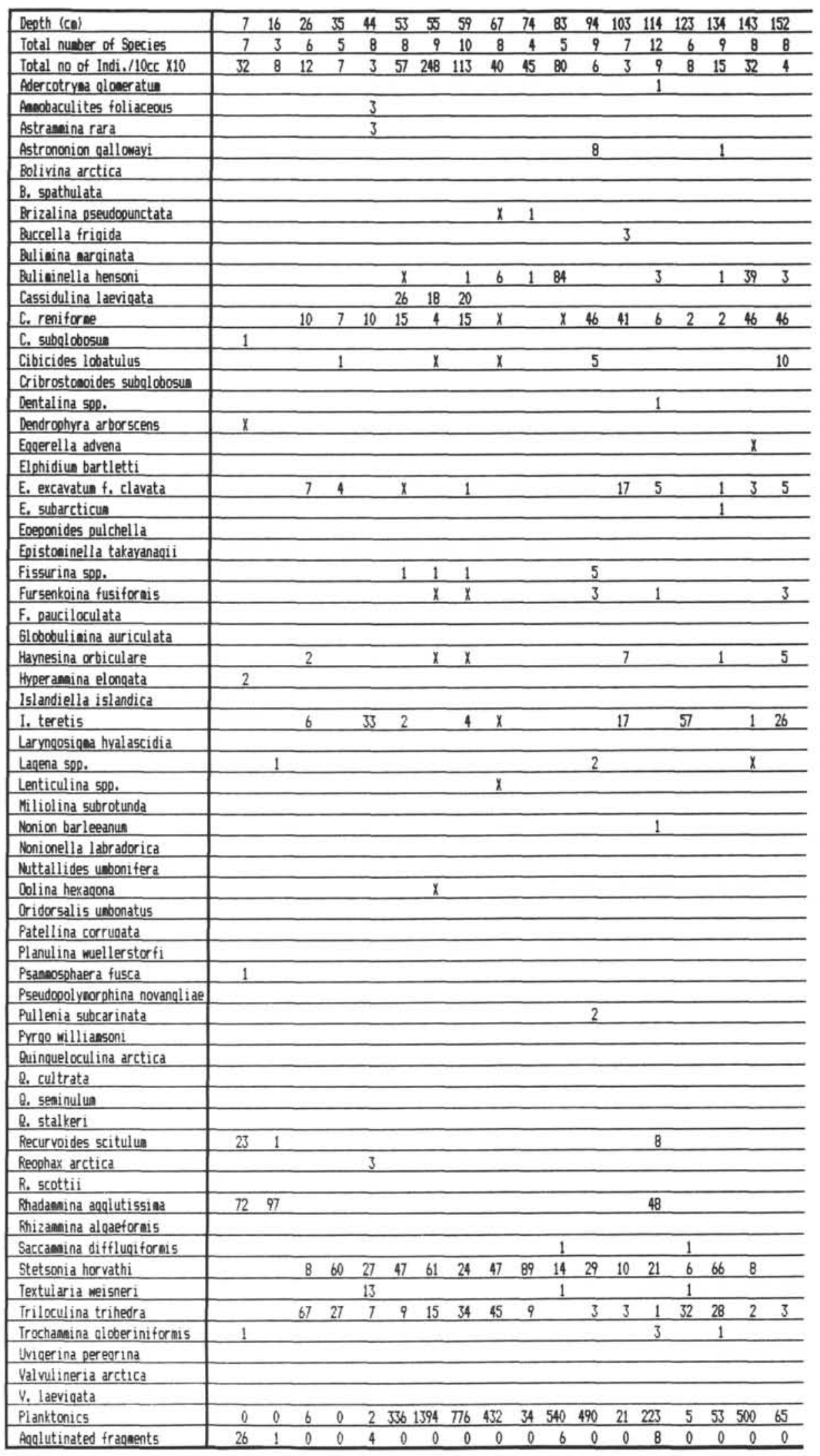


Table 1 (continued).

\section{PISTON $(6-286 \mathrm{~cm})$}

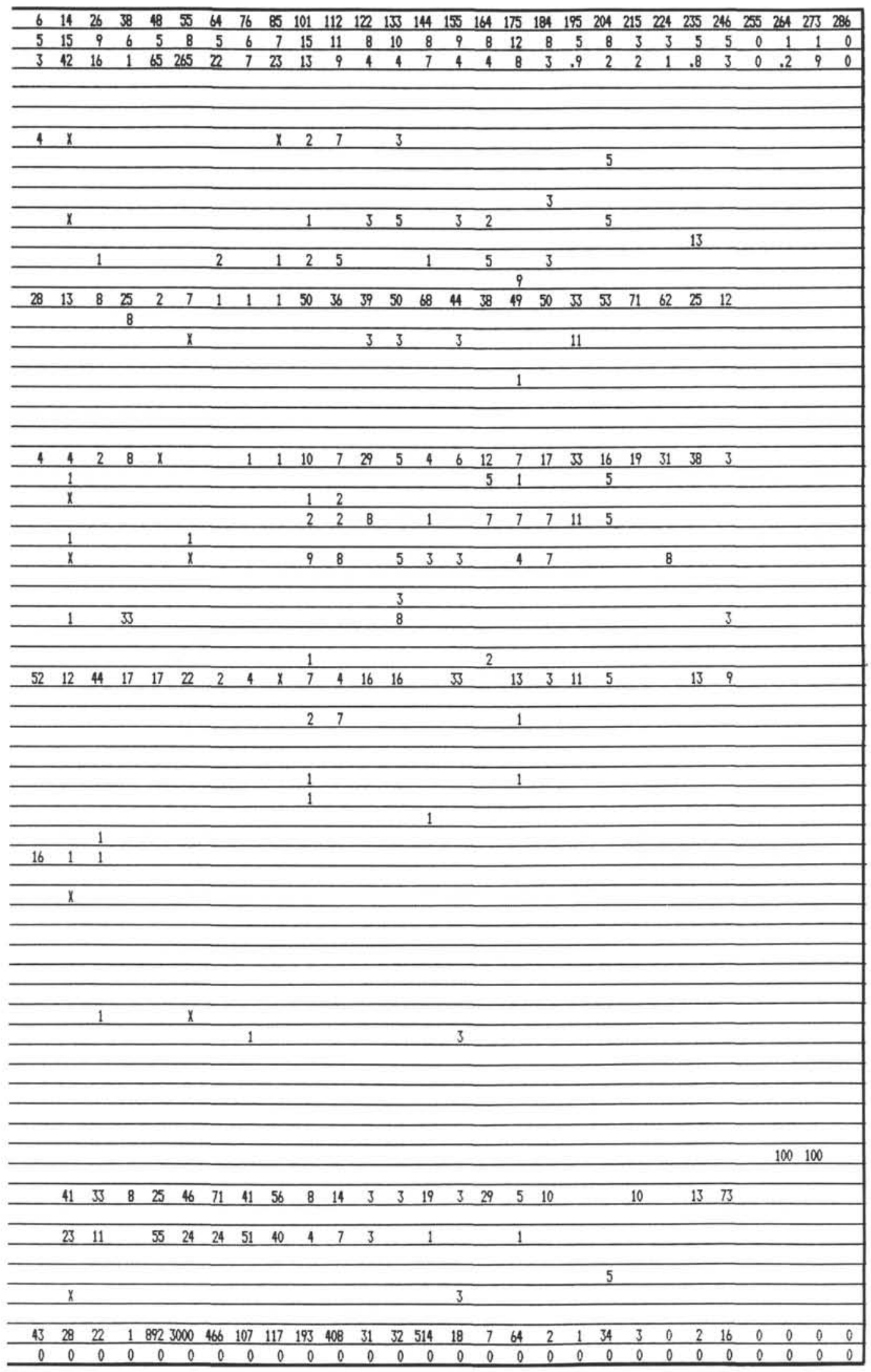


D. B. SCOTT ET AL.

Table 1 (continued).

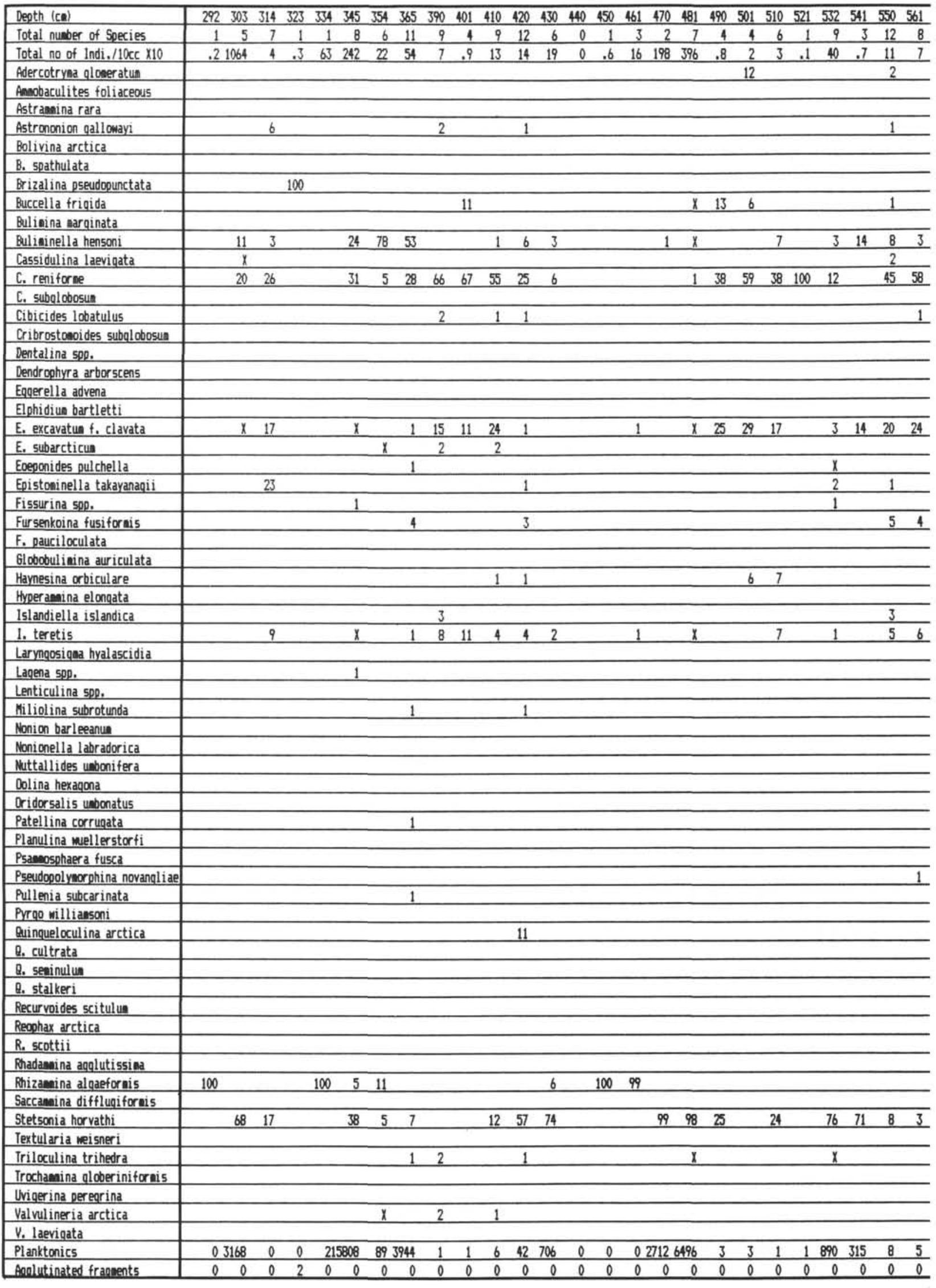


Table 1 (continued).

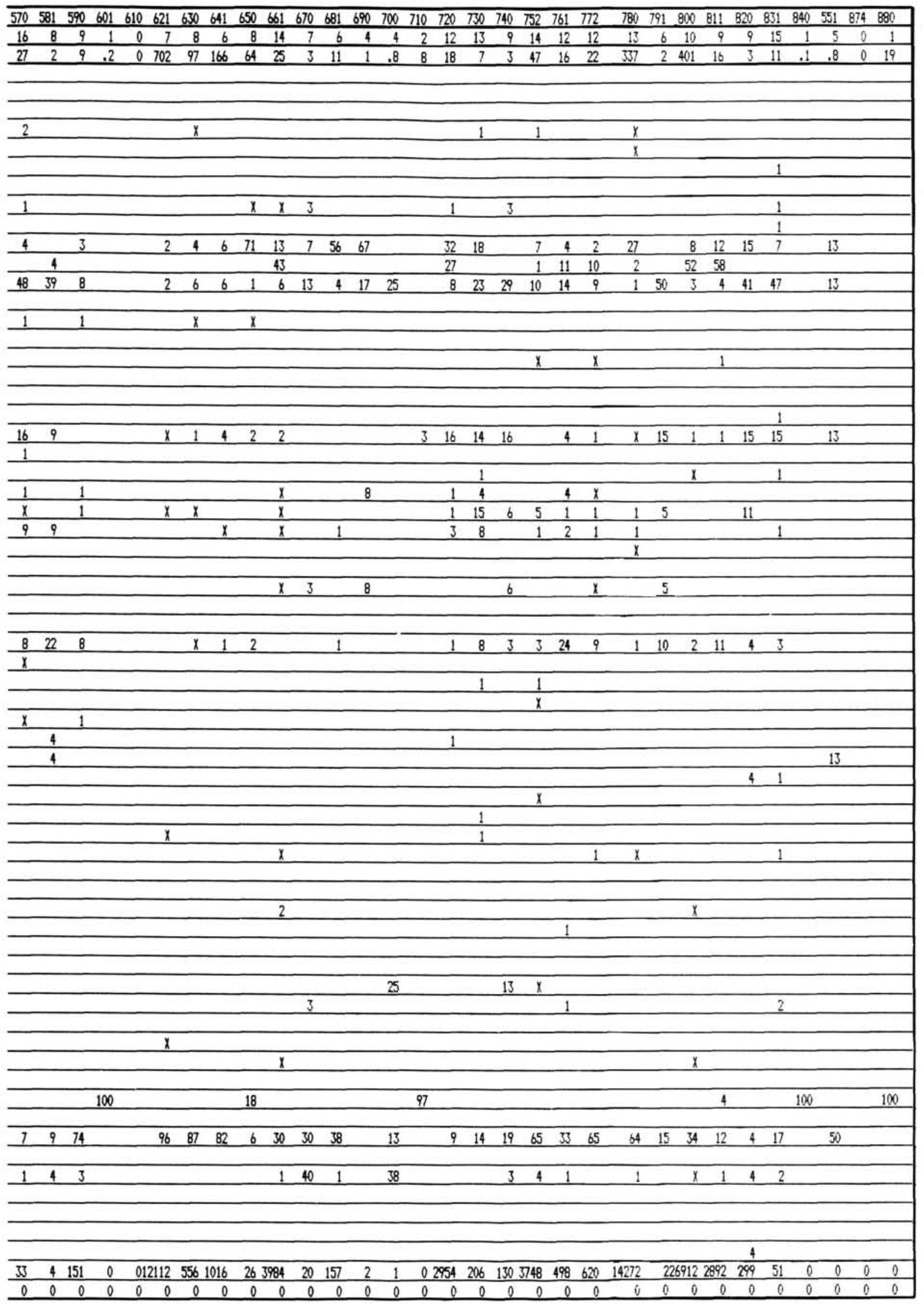


T.W.C. $(0-148 \mathrm{~cm})$

PISTON $(0-254 \mathrm{~cm})$

\begin{tabular}{|c|c|c|}
\hline Depth $(c a)$ & $\begin{array}{llllllllllllllllll}0 & 8 & 18 & 28 & 38 & 48 & 58 & 68 & 78 & 88 & 98 & 108 & 118 & 128 & 135 & 139 & 148 \\
\end{array}$ & $\begin{array}{llllllllllllllllllllllllllllll}0 & 10 & 17 & 28 & 38 & 48 & 58 & 68 & 71 & 78 & 88 & 98 & 108 & 118 & 128 & 138 & 148 & 158 & 170 & 174 & 178 & 188 & 198 & 208 & 218 & 22 & 228 & 238 & 248\end{array}$ \\
\hline Total number of Species & $\begin{array}{lllllllllllllllll}5 ! & 46 & 47 & 40 & 38 & 43 & 31 & 38 & 26 & 42 & 46 & 42 & 29 & 25 & 54 & 45 & 20 \\
\end{array}$ & 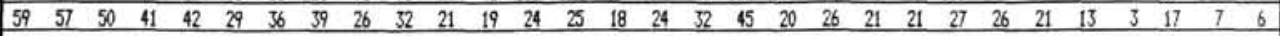 \\
\hline Iotal no of Indi. $/ 10 \mathrm{cc} \times 10$ & 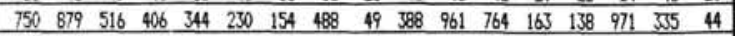 & 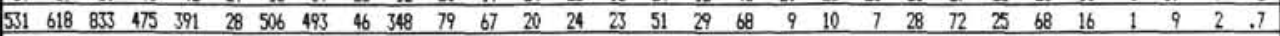 \\
\hline Adercotryed qloaer atun & 3111 & 11 \\
\hline Astracoius crepidulus & & $x$ \\
\hline A. insolitus & $x$ & \\
\hline Astrononion qallowavi & $x$ & $x \quad x$ \\
\hline Bolivina arctica & $x \times$ & \\
\hline B. pseudoplicata & & $x$ \\
\hline B. robusta & $\begin{array}{llllll}x & x & x & x & x & x \\
\end{array}$ & $\begin{array}{lllllll} & x & 1 & 1 & 1 & 1 \\
\end{array}$ \\
\hline B. spathulata & ( & \\
\hline B. subspinescens & $1 \times x$ & 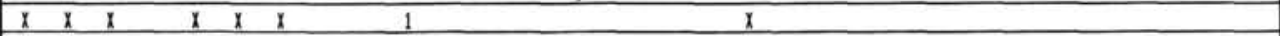 \\
\hline Brizalina pseudopunctata & $\begin{array}{cccccccccccc}x & x & x & x & x & 2 & 1 & 1 & x & x & 1 & x \\
\end{array}$ & \begin{tabular}{|llllllllllll}
$x$ & 1 & $x$ & $x$ & $x$ & $x$ & 1 & $x$ & $x$ & 1 & 1 \\
\end{tabular} \\
\hline Buccella friqida & $2 \quad x$ & 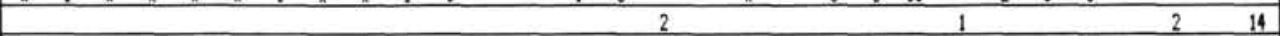 \\
\hline Bulinina exilis & $x$ & \\
\hline B. qibba & & 1 \\
\hline 8. notovata & $x \times x$ & $x$ \\
\hline Rulieinel la hensoni & $x \times 2$ & \begin{tabular}{|lll}
$x$ & $x$ & $x$ \\
\end{tabular} \\
\hline Carterind soiculotesta & & 11 \\
\hline Cassidulina reniforne & $\begin{array}{lllllllllllllllll}2 & 2 & 2 & 1 & 4 & 1 & 1 & 1 & 4 & 1 & 2 & 1 & 2 & 1 & 2 & 2 & 2\end{array}$ & $\begin{array}{lllllllllllllll}2 & 2 & 5 & 3 & 5 & 2 & 5 & 6 & 18 & 1 & 9 & 20 & 1 & 8 & 5 \\
\end{array}$ \\
\hline C. subalobosua & $\begin{array}{lllllllllllllllll}1 & 1 & 1 & x & 1 & x & x & 1 & x & x & x & x & 2 & & 1 & 1 & 1\end{array}$ & $\begin{array}{lllllllllll}2 & 2 & 2 & 3 & 4 & 1 & 4 & 11 & 4 & 15 & 15\end{array}$ \\
\hline Cassidulinoides bradyi & (2) & \\
\hline Cibicides lobatulus & $\begin{array}{llll} & 1 & x & x \\
\end{array}$ & $\begin{array}{llllll}2 & 3 & 2 & 1 & \times & 2 \\
\end{array}$ \\
\hline C. pseudoungerianus & & $x \times$ \\
\hline C. robertsonianus & & $x x$ \\
\hline C. subhaidinger ii & $x$ & $\begin{array}{ll}x & 1 \\
\end{array}$ \\
\hline Cribrostomoides crassinar qo & & $x$ \\
\hline C. subqlobosina & $1 x$ & $x x$ \\
\hline Dentalina 5pp. & \begin{tabular}{llllllll|}
$x$ & $x$ & 1 & 1 & 1 & $x$ & $x$ & 1 \\
\end{tabular} & $\begin{array}{llllllllllllll}1 & x & x & x & 1 & 1 & 1 & 1 & x & 1 & 1 & 4 & 1 & 1 \\
\end{array}$ \\
\hline Discopulvinulina spp. & 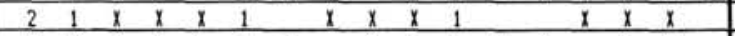 & $1 \times x \times x$ \\
\hline Discarbis 5pp. & 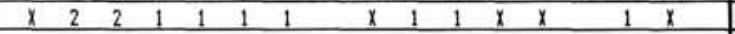 & \begin{tabular}{lllll|}
1 & 1 & 1 & 1 & 1 \\
\end{tabular} \\
\hline Elphidiun bartletti & & 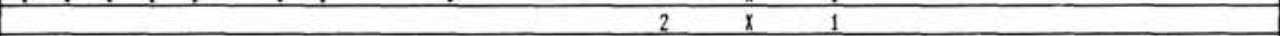 \\
\hline E. excavatur & & 1 \\
\hline E. excavatua forea clavata & $\begin{array}{lllllllllllllllll}2 & 2 & 4 & 2 & 3 & 3 & 4 & 2 & 2 & 1 & 2 & 2 & 1 & 1 & 3 & 3 & x \\
\end{array}$ & $\begin{array}{|llllllllll|}3 & 3 & 3 & 2 & 3 & 1 & 3 & 3 & 1 & 2 \\
\end{array}$ \\
\hline \multicolumn{3}{|c|}{ 2. } \\
\hline E. incertuin & & $x$ \\
\hline \multicolumn{3}{|l|}{ E. subarcticun } \\
\hline E. ustalatun & & 13 \\
\hline Equerella advena & & \begin{tabular}{|l|l}
$x$ \\
\end{tabular} \\
\hline Eqgerella bradyi & & 21 \\
\hline Epistoninella exiqua & \begin{tabular}{lllllllllllllllll|}
11 & 9 & 1 & 14 & 15 & 25 & 28 & 20 & 21 & 25 & 16 & 18 & 13 & 3 & 12 & 18 & 2 \\
\end{tabular} & 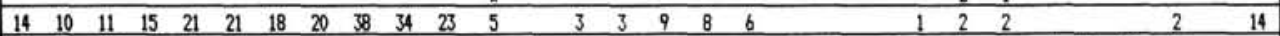 \\
\hline Eponides bradyi & \begin{tabular}{lllllllllllllllll|}
16 & 21 & 21 & 26 & 19 & 13 & 9 & 12 & 16 & 15 & 15 & 11 & 12 & 14 & 20 & 12 & 10 \\
\end{tabular} & 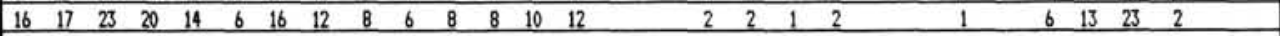 \\
\hline E. tunidulus & $\begin{array}{cccccccccccccccc}1 & 1 & 1 & 1 & x & 1 & 1 & 1 & 2 & 1 & 1 & 1 & x & 1 & 2 & 1\end{array}$ & $\begin{array}{llllllllllllllll}1 & 1 & 1 & 2 & 2 & 2 & 2 & 2 & 2 & 2 & 2 & 2 & 2 & 1 & 3\end{array}$ \\
\hline Fissurina spp. & 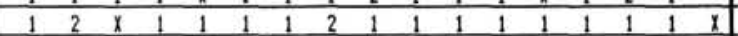 & 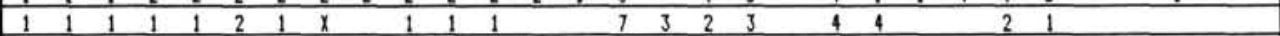 \\
\hline Fursenkoina fusifornis & \begin{tabular}{lllllllllllllllll|}
6 & 11 & 11 & 7 & 7 & 10 & 6 & 12 & 7 & 10 & 11 & 17 & 13 & 26 & 11 & 12 & 13
\end{tabular} & $\begin{array}{lllllllllllllllllllllllll}5 & 12 & 11 & 9 & 11 & 15 & 12 & 16 & 8 & 8 & 9 & 12 & 14 & 12 & 3 & 2 & 4 & 2 & 5 & 14 & 6 & 2 & 15 & 4 & 8\end{array}$ \\
\hline Globobulinina auriculata & $x \times$ & $x 2$ \\
\hline \multicolumn{3}{|l|}{ Globobulinina spp. } \\
\hline 6locospira gordialis & $1 \quad 1 \quad 1 \quad x \quad x \quad x$ & $12 x$ \\
\hline Guttulina spo. & & $\frac{x}{x}$ \\
\hline Groidina soldani & \begin{tabular}{lllllllllllllllll|}
$x$ & $x$ & $x$ & 1 & 2 & 2 & $x$ & $x$ & 4 & 2 & 2 & 1 & 3 & 1 & 1 & 3 & 4
\end{tabular} & 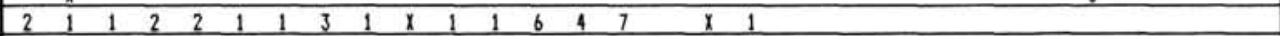 \\
\hline Hamesina orbiculare & & $x \quad x$ \\
\hline Hoeqlundina eleqans & 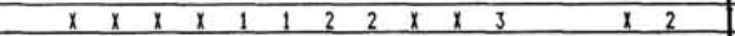 & $1 \times 1111112$ \\
\hline Hyalinea balthica & & $x \quad x$ \\
\hline Hyper amina subnodosa & & $x$ \\
\hline Hyperamina spp. & 111 & 11 \\
\hline $\begin{array}{l}\text { Islandiella teretis } \\
\end{array}$ & $1 \times 1 \times 1$ & $x=1 \times x$ \\
\hline Karriella apicularis & $1 \times$ & $1 \times x$ \\
\hline K. bradyi & & \\
\hline
\end{tabular}


Table 2 (continued).

\begin{tabular}{|c|c|c|}
\hline Lagena spp. & $\begin{array}{llllllllllllllll}x & 2 & 2 & 1 & 1 & 2 & 2 & 3 & 2 & 3 & 2 & \times & 1 & 1 & 2 & 2 \\
\end{array}$ & $\begin{array}{lllll}3 & 1 & 1 & 2 & 2 \\
\end{array}$ \\
\hline Lenticulina spp. & $\begin{array}{lllll}x & x & 1 & 1 & x \\
\end{array}$ & $x \times x \times$ \\
\hline Miliolina spe. & $x$ & \\
\hline Modosaria lamulifera & & 1 \\
\hline \multicolumn{3}{|l|}{ N. 5ppo. } \\
\hline Nonion barleaeanua & \begin{tabular}{lllllllllllllllll|}
2 & 1 & 2 & 4 & 4 & 3 & 6 & 3 & 13 & 6 & 2 & 6 & 9 & 5 & 2 & 5 & 15 \\
\end{tabular} & $\begin{array}{llllllllllllllllllllll}3 & 1 & 2 & 5 & 4 & 10 & 6 & 7 & 12 & 8 & 9 & 13 & 18 & 4 & 7 & 5 & 4 & 5 & 8 & 4 & 9 & 4\end{array}$ \\
\hline Nonionella turqida & $1 \quad 1 \times \times \times \times \times 1$ & $\begin{array}{llllll}x & x & x & x & 1 & x \\
\end{array}$ \\
\hline Wutlalides unbonifera & $x$ & $x \quad x \times 12$ \\
\hline Dolina 5po. & \begin{tabular}{llllllll|}
$x$ & 1 & 1 & 1 & 1 & $x$ & 1 & 1 \\
\end{tabular} & $\begin{array}{lllllllllllll} & 1 & 1 & 1 & 1 & 2 & 1 & 1 & 1 & 1 & 1 & 1 & 3 \\
\end{array}$ \\
\hline Qothalnidiua acutinarno & $x \times x \times x$ & $x \times \times \times \times$ \\
\hline Oridorsal is uebonatus & 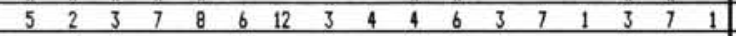 & $\begin{array}{lllllllllll}7 & 3 & 3 & 10 & 5 & 4 & 3 & 2 & 2 & 2 & 1 \\
\end{array}$ \\
\hline Patellina corrugata & $\begin{array}{lllll}x & x & x & x & x \\
\end{array}$ & $\begin{array}{ccccccc}x & x & x & x & x & x & x \\
\end{array}$ \\
\hline Planulina weellerstor $f i$ & $\begin{array}{|lllllllllllllllll|}4 & 2 & 7 & 6 & 7 & 4 & 3 & 4 & 2 & 5 & 6 & 3 & 2 & 4 & 5 & 6 & 3 \\
\end{array}$ & $\begin{array}{llllllllllllllllllllllllll}5 & 5 & 5 & 8 & 3 & 3 & 4 & 2 & 4 & 1 & 6 & 6 & 3 & 7 & 17 & 6 & 1 & 8 & 2 & 8 & 7 & 6 & 2 & 11 & 1 & 3 \\
\end{array}$ \\
\hline Planulina 5pp. & $x \times x$ & $\times 1 \times$ \\
\hline Psamosphaera fusca & 212 & 11 \\
\hline Pseudopolyeorphina novangliae & $x$ & $x$ \\
\hline Pullenia bulloides & \begin{tabular}{lllllllllllllllll|}
2 & 1 & 3 & 4 & 1 & 1 & 3 & 2 & 3 & 1 & 1 & 1 & 3 & 1 & 2 & 2 & $x$ \\
\end{tabular} & $\begin{array}{llllllllllllll}2 & 7 & 3 & 6 & 7 & 7 & 6 & 4 & 2 & 2 & 5 \\
\end{array}$ \\
\hline P. subcarinata & 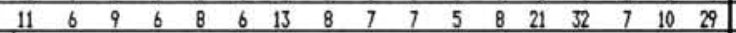 & 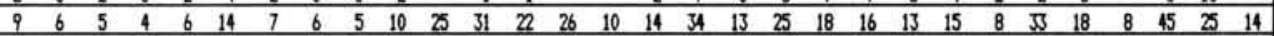 \\
\hline Pyrqo villiansoni & $x \quad x \quad x \quad x \quad x \quad 1 \quad x \quad x \quad x \quad x \quad x \quad x$ & $1 \times 1 \times x$ \\
\hline Pyrulina qutta & $x \times$ & \\
\hline lina agqutitinans & $x$ & \\
\hline Q. cultrata & $1 \times 1 \times 1 \quad 1 \quad x$ & $\begin{array}{llll}x & x & x & 1 \\
\end{array}$ \\
\hline Q. seainulua & $\begin{array}{lllllllll} & x & x & 1 & 1 & x & x & 1 & x\end{array}$ & $1 \quad x \quad 1 \quad 1 \quad 1$ \\
\hline Reophax bacillaris & $\begin{array}{lllll}x & x & 1 & x \\
\end{array}$ & $1 \quad 1 \times x \times 1$ \\
\hline \multicolumn{3}{|l|}{ R. scorpiurus } \\
\hline Ftizamina algaefornis & 1 & \\
\hline \multicolumn{3}{|l|}{ R. spp. } \\
\hline Robertinoides charlottensis & & \\
\hline Saccanaina difflugifornis & $2 \times x$ & $41 x$ \\
\hline S. sohaera & & $1 x$ \\
\hline Sigaoilogsis schlumbergeri & $\begin{array}{ll}x & x \\
\end{array}$ & $\begin{array}{lll}x & x & x \\
\end{array}$ \\
\hline Sphaeroidina bulloides & & 1 \\
\hline Spiroplectamina bifornis & 221 & $11 x$ \\
\hline Stetsonia horvathi & $\begin{array}{lllllllllllll}2 & 6 & 4 & 1 & 2 & 3 & 1 & 3 & x & 2 & 7 & 7 & x\end{array}$ & $\begin{array}{llllllllllll}1 & 3 & 5 & 2 & 3 & \times & 2 & 4 & \times & 6 & 3 & 2\end{array}$ \\
\hline Siphotextul aria rol shauseni & $1 \times x \times 1 \quad 1 \quad x$ & $\begin{array}{lllllllll}x & 1 & \times & \times & x & 1 & \times & 1 & 2 \\
\end{array}$ \\
\hline Tosaia hanzakai & $\begin{array}{llllll}x & x & x & x & x & x\end{array}$ & $\begin{array}{lllllllll}3 & 6 & 5 & 4 & 5 & 1 & 7 & 6 & 2 \\
\end{array}$ \\
\hline Irifarin: & \begin{tabular}{llllll|}
$x$ & $x$ & 1 & 1 & 1 & 1 \\
\end{tabular} & \\
\hline Triloculina arctica & $\begin{array}{lllllll} & x & x & x & 1 & 2 & x \\
\end{array}$ & $\begin{array}{cccccc} & x & x & 3 & x & x \\
\end{array}$ \\
\hline I. trihedra & $\begin{array}{llllllllllllllll}2 & 2 & 2 & 2 & 2 & 2 & 2 & 6 & 3 & 1 & 5 & 5 & \times & 1 & 2 & 3\end{array}$ & $\begin{array}{llllllllllll}1 & 6 & 7 & 6 & 2 & 9 & 11 & 4 & 7 & 9 & 8 & 2 \\
\end{array}$ \\
\hline Trochamina nana & $x$ & $x$ \\
\hline T. pacifica & & $x \quad 1 \quad x$ \\
\hline Irochamai & $3 x$ & $x$ \\
\hline Trochaminella atlantica & $\begin{array}{|llll|}5 & 3 & 6 & 1 \\
\end{array}$ & $4 \quad 2$ \\
\hline sperula & 12 & $\begin{array}{lllll}1 & 2 & 11 & 2 & 3 \\
\end{array}$ \\
\hline U. per & 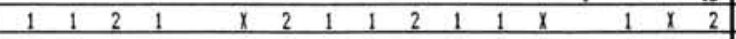 & $\begin{array}{llllllllllll}1 & 2 & 2 & 1 & 1 & 1 & 1 & 1 & 1 & 1 & 1 & 1 \\
\end{array}$ \\
\hline Valvulineria arctica & $\begin{array}{lllllllllllll}x & 10 & 5 & 4 & 6 & 5 & 1 & 8 & 1 & 3 & 8 & 5 & x \\
\end{array}$ & $\begin{array}{llllllllll}4 & 7 & 8 & 5 & 8 & 1 & 7 & 4 & 1 & 1 \\
\end{array}$ \\
\hline
\end{tabular}




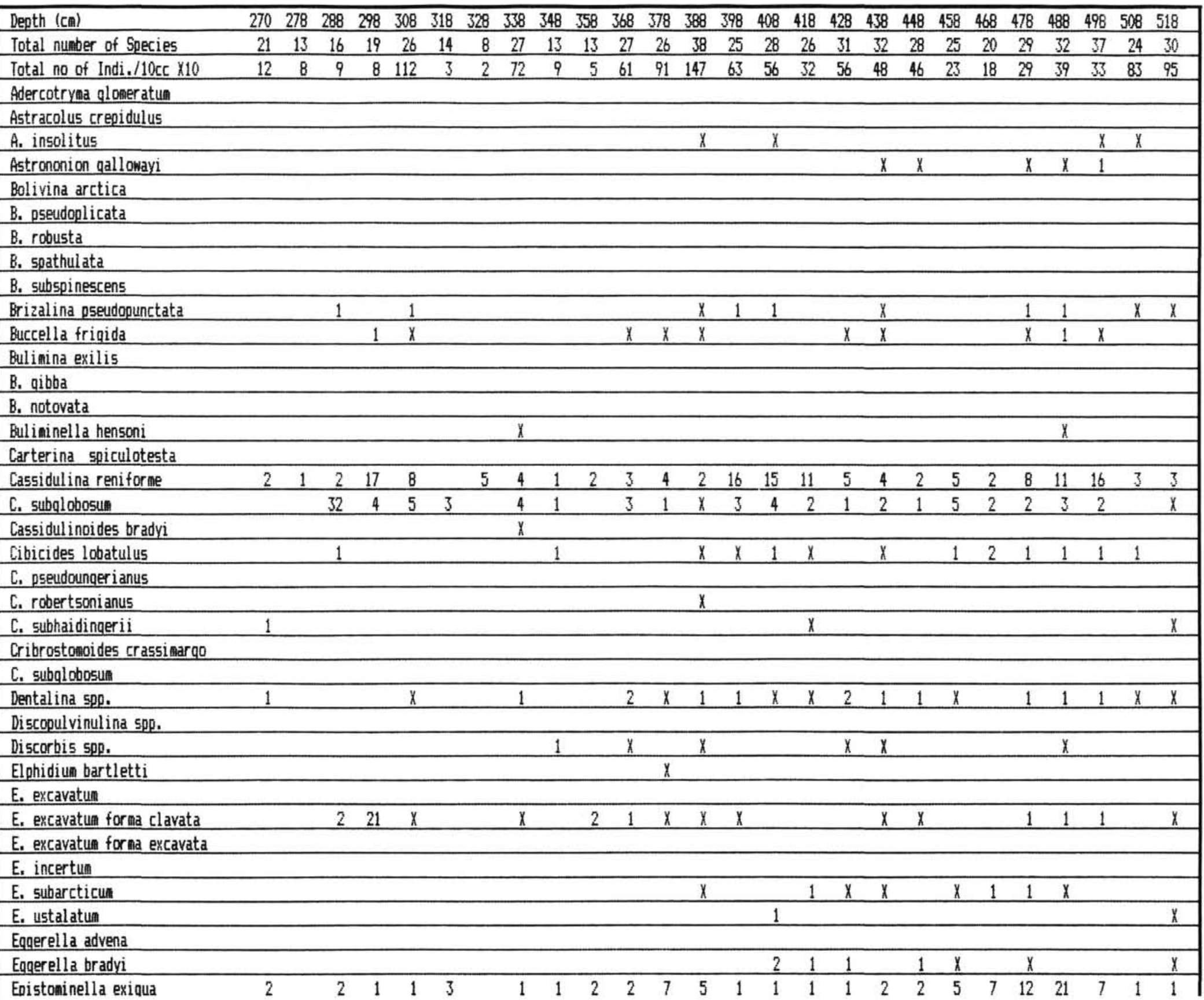


Table 2 (continued).

\begin{tabular}{|c|c|c|c|c|c|c|c|c|c|c|c|c|c|c|c|c|c|c|c|c|c|c|c|c|c|c|c|}
\hline Eponides bradyi & 13 & 1 & 20 & 5 & 3 & 7 & 10 & 9 & 16 & 34 & 4 & 2 & 3 & 15 & 14 & 16 & 9 & 5 & 8 & 11 & 9 & 2 & 1 & 4 & 6 & & $L$ \\
\hline E. tunidulus & & & 2 & & $x$ & 3 & & 1 & & & 1 & $x$ & & & $x$ & $x$ & 1 & $x$ & 1 & & & & 1 & $x$ & 1 & & 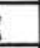 \\
\hline Fissurina spp. & 5 & & & & & 40 & & & 10 & & & $x$ & 2 & 1 & 1 & 1 & 1 & $x$ & 1 & 1 & & $x$ & 1 & 2 & 1 & & \\
\hline Fursenkoina fusi formis & 2 & & 2 & 4 & 2 & & 5 & 3 & & 2 & 3 & 1 & 2 & 6 & 3 & 3 & 3 & 3 & 2 & 3 & 3 & 2 & 5 & 3 & 4 & & \\
\hline Globobulinina auriculata & & & & & & & & & & & & & & & & & & & & & & & 1 & & $x$ & & \\
\hline \multicolumn{27}{|l|}{ Globobulinina spp. } & \\
\hline Glomospira qordialis & & & & & & & & & & & & & & & & & & & & & & & & & & & \\
\hline \multicolumn{28}{|l|}{ Guttulina spp. } \\
\hline Gyroidina soldani & 1 & 1 & & & & & & & & & & $x$ & $x$ & 1 & 2 & $x$ & 1 & & $x$ & 1 & & & & 1 & $x$ & & \\
\hline Haynesina orbiculare & & & & & & & & & & & & $x$ & $x$ & & & & $x$ & $x$ & & & 1 & & $x$ & $x$ & & & \\
\hline Hoeqlundina eleqans & & 1 & & & & & & & & & & & & & & & & & & & & & & & & & \\
\hline Hyalinea balthica & & & & & & & & & & & & & & & & & & & & & & & & $x$ & & & \\
\hline \multicolumn{28}{|l|}{ Hyper ammina subnodosa } \\
\hline \multicolumn{28}{|l|}{ Hyper ammina spp. } \\
\hline Islandiella teretis & 1 & & & & & 3 & & & & & & & $x$ & & & & & & & & & 1 & $x$ & 1 & & & \\
\hline \multicolumn{27}{|l|}{ Karriella apicularis } & \\
\hline K. bradyi & & & & & & & & & & & & & & & & & & & & & & & & $x$ & & & \\
\hline Laqena spp. & 3 & 2 & 1 & 3 & $x$ & 3 & & 3 & 2 & & $x$ & 1 & 1 & 4 & 1 & 3 & 3 & 2 & 2 & 2 & & 2 & 1 & 1 & 1 & & \\
\hline \multicolumn{27}{|l|}{ Lenticulina spp. } & \\
\hline Miliolina spp. & & & & & $x$ & & & & & & & & & & & & & & & & & & $x$ & 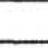 & & & \\
\hline \multicolumn{27}{|l|}{ Nodosaria lamnulifera } & \\
\hline N. $5 p p$. & & & & & & & & & & & & & & & & & & & & & & & & $x$ & & & \\
\hline Nonion barleeanum & 21 & 4 & 17 & & & 3 & 29 & 11 & 17 & 17 & 4 & 5 & 7 & 11 & 14 & 14 & 7 & 4 & 7 & 9 & 5 & 5 & 2 & 3 & 14 & & \\
\hline Nonionella turqida & & & & 1 & & & & & & & & & & & & & & & & & & & & & & & \\
\hline Nutlal ides umbonifera & & & & & 6 & & & 1 & & 2 & 1 & $y$ & $x$ & & & & $x$ & $x$ & 1 & 2 & 13 & 12 & 14 & $x$ & & & \\
\hline Dolina spp. & 1 & 1 & 1 & & 1 & 3 & & 1 & 1 & & 1 & 1 & 1 & 1 & $x$ & 1 & 1 & 2 & 2 & 3 & 2 & 1 & 2 & 5 & $x$ & & \\
\hline Opthalnidiun acutimarno & 1 & & & & & & & & & & & & $x$ & & $\bar{x}$ & & $x$ & $x$ & $x$ & & & & & 2 & & & \\
\hline Gridorsalis umbonatus & 1 & 1 & & 1 & & & & $x$ & & 2 & & & $x$ & $x^{\prime}$ & 2 & 1 & 1 & & $x$ & 1 & 2 & 1 & $x$ & 1 & 2 & & \\
\hline \multicolumn{28}{|l|}{ Patellina corruqata } \\
\hline Planulina wuellerstorfi & & & & 9 & 7 & 3 & 5 & 6 & & & 5 & 4 & 6 & 2 & 3 & 5 & 5 & 6 & 7 & 4 & 2 & 4 & 3 & 3 & 3 & & \\
\hline \multicolumn{28}{|l|}{ Planulina spp. } \\
\hline \multicolumn{28}{|l|}{ Psammosphaera fusca } \\
\hline \multicolumn{28}{|c|}{ Pseudopol yoorphina novanqliae } \\
\hline Pullenia bulloides & 3 & 1 & 1 & 1 & 3 & 3 & 14 & 3 & 8 & 6 & 2 & 2 & 4 & 1 & 1 & 1 & 3 & 3 & 4 & 4 & 7 & 6 & 3 & 1 & $x$ & & \\
\hline Pi subcarinata & 12 & 11 & 10 & 1 & 16 & 53 & 24 & 31 & 7 & 6 & $?$ & 12 & 15 & 24 & 20 & 27 & 16 & 23 & 27 & 36 & 37 & 23 & 17 & 7 & 19 & 1 & \\
\hline Pyrqo williamsoni & & & 1 & 1 & 1 & & & & & & $x$ & & 1 & $x$ & & & 2 & 1 & 1 & $x$ & 1 & 1 & 1 & 3 & 2 & & \\
\hline \multicolumn{28}{|l|}{ Pyrulina qutta } \\
\hline \multicolumn{28}{|c|}{ Quinquel ocul ina aqqlutinans } \\
\hline Q. cultrata & 1 & & & & 1 & & & 2 & & & 1 & 1 & 1 & $x$ & $x$ & 1 & 1 & 1 & 1 & $x$ & & & & 1 & & & \\
\hline Q. seninulum & & & & & & & & & & & & & $x$ & & & & & & & & & & & & & & \\
\hline
\end{tabular}


Table 2 (continued).

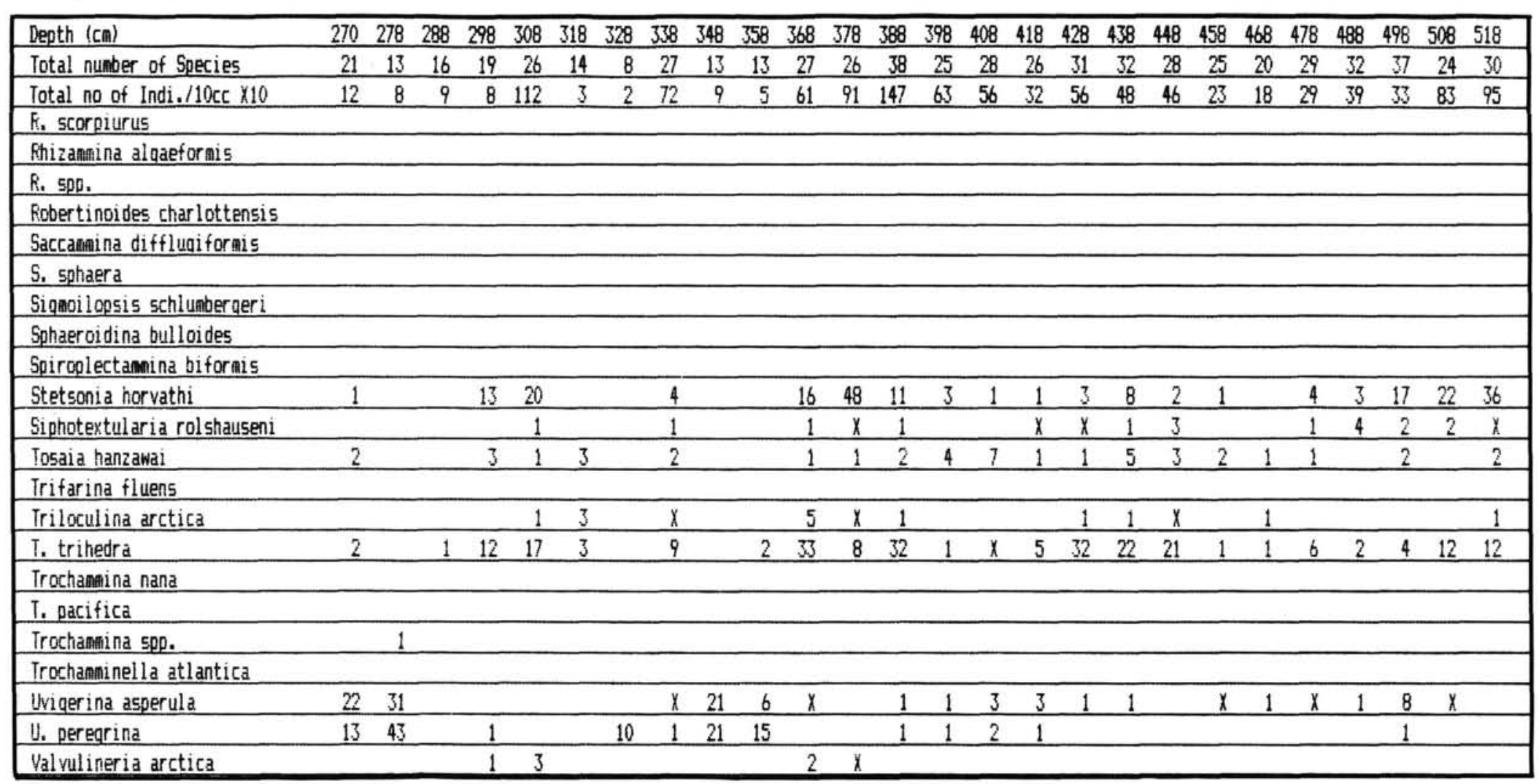



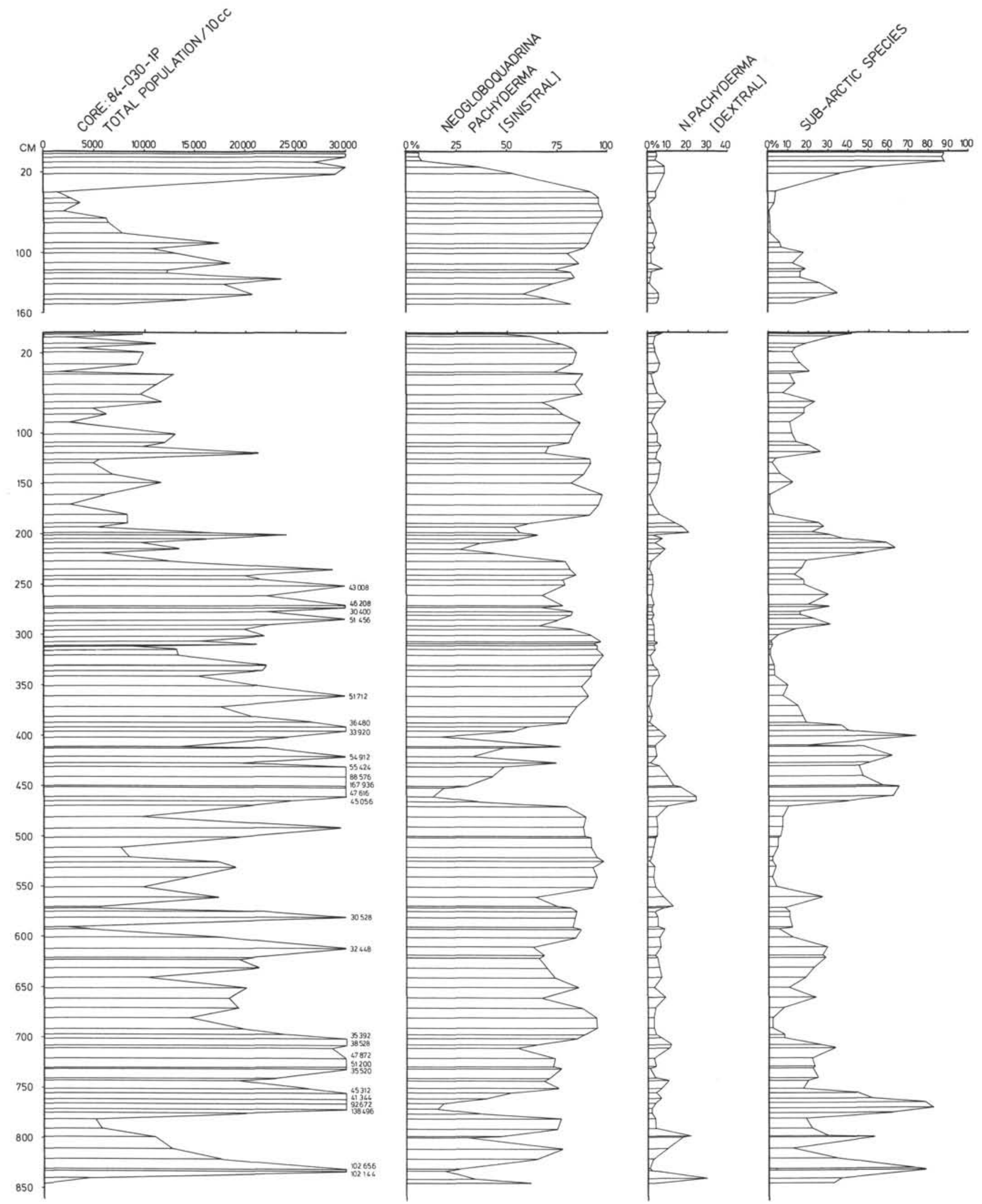

Figure 8. Planktonic assemblages vs. total carbonate and stable isotopes for Labrador Sea Core 84-030-01 TWC and PC. Stippled area on carbonate curve is dolomite. 
D. B. SCOTT ET AL.

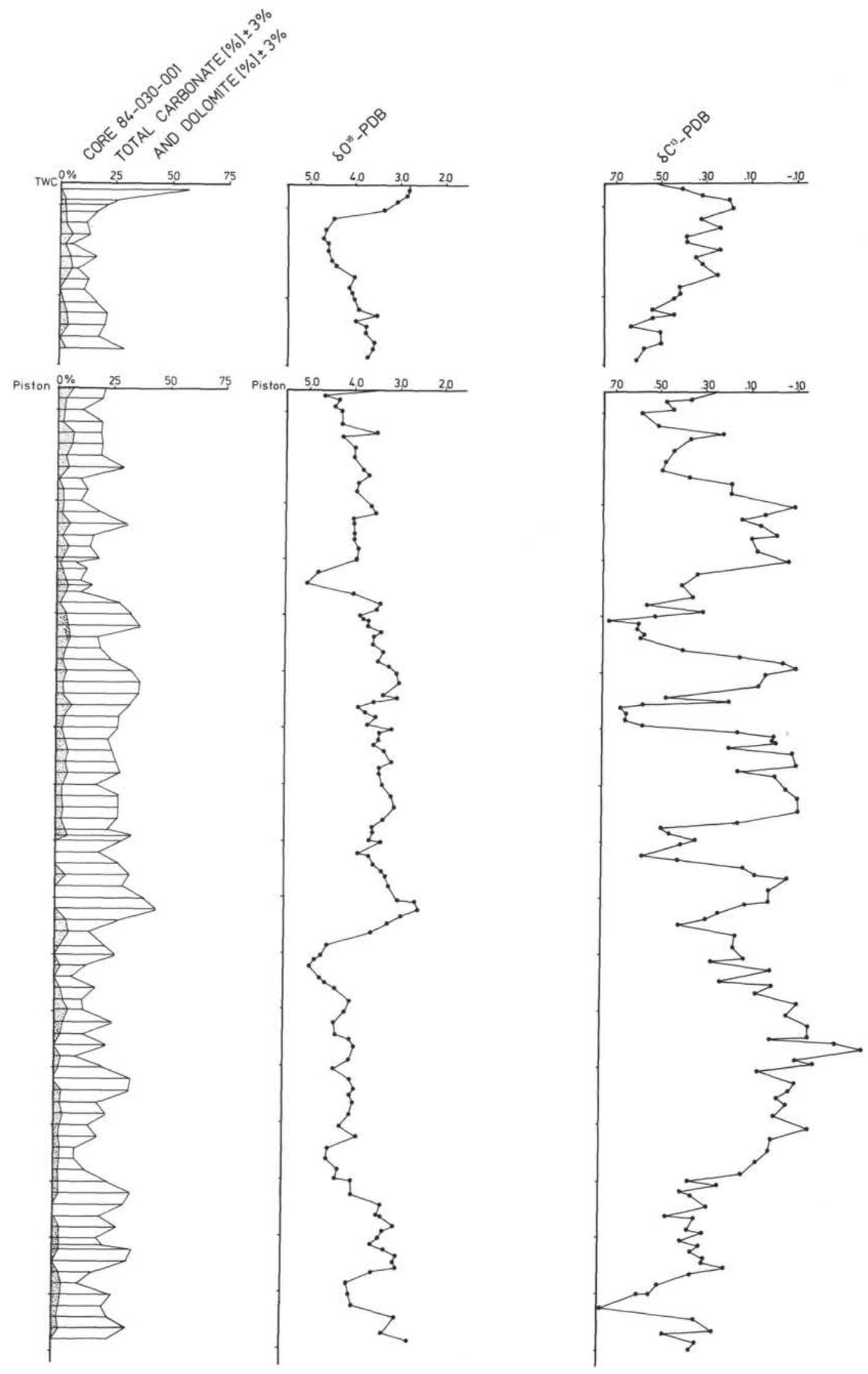

Figure 8 (continued). 